\title{
Text and lineage in early Sikh history: issues in the study of the Adi Granth ${ }^{1}$
}

\author{
JEEVAN SINGH DEOL \\ St John's College, Cambridge
}

Perhaps the most controversial area within Sikh studies has been the textual study of the Adi Granth, the Sikh scripture. Although textual study has yet to be pursued with any vigour, it has in recent years been the area of Sikh studies which has consistently produced the most vehement reactions. ${ }^{2}$ There are, as is to be expected, a number of reasons for this strong resistance to the textual study of the Adi Granth, the most prominent being that the doctrine of the Granth as Guru appears to have produced a strong reluctance to interrogate its textual history. Despite the strength of reactions to scholarly work on the Adi Granth, though, much of the non-traditional work on its textual history has not strayed far from the boundaries demarcated by tradition, concentrating only on a limited number of textual issues. Neither the new writing nor the traditionalist responses to it have taken into account the work being carried out within neighbouring textual and devotional traditions, particularly the work being carried out on the oral and written transmission of contemporaneous north Indian nirguna devotional literature. ${ }^{3}$ Equally, neither strand of writing has engaged with the post-colonial critique of the long history of Western textualist endeavours to create and 'correct' South Asian texts.

While classical South Asian textual traditions display a strong emphasis

${ }^{1}$ Fieldwork in India was funded by grants from the Social Sciences and Humanities Research Council of Canada and the Shastri Indo-Canadian Institute. Neither body is responsible for the views expressed in the paper. The Adi Granth manuscripts at Takht Srī Harimandir Sāhib, Patna were seen there in November 1998; I would like to thank S. S. Ahluwalia and Dr Mohinder Singh of New Delhi for making access to the texts possible. Dr Darshan Singh of Punjabi University, Patiala, Professor Christopher Shackle of the School of Oriental and African Studies, London, Amandeep Singh Madra and Parmjit Singh kindly read and commented on earlier drafts of the paper. Proper names of individuals have been transliterated in their modern Punjabi or Hindi forms. Common terms such as the names of the Sikh Gurus and the Adi Granth, major cities, districts and district headquarters have not been given diacritics. Quotations from texts, titles of pre-twentieth century texts and literary terms have been given in their 'pre-modern' forms with 'silent' $a$ (excepting janamsākhì and shabad, which are given in their modern Punjabi forms). Other terms are transliterated in their modern Punjabi forms. In accordance with the general usage for the transliteration of Punjabi, I have used $c h, c h h$ and $s h$ for the characters usually represented in Indological transcriptions as $c, c h$ and $s$, respectively. Unless otherwise noted, all dates are C.E. This paper was completed in 1999. It has therefore not been possible to include works published after that date, e.g. Balwant Singh Dhillon, Early Sikh scriptural tradition: myth and reality (Amritsar: Singh Brothers, 2000) and Pashaura Singh, The Guru Granth Sahib: canon, meaning and authority (New Delhi: Oxford University Press, 2000).

${ }^{2}$ For a particularly tendentious example, see Bachittar Singh Giani (ed.), Planned attack on Aad Siri Guru Granth Sahib [:] Academics or blasphemy [?] (Chandigarh: International Centre of Sikh Studies, 1994).

${ }^{3}$ For theoretical approaches to this literature, see, for example, Kenneth E. Bryant, 'Toward a critical edition of the Sürasāgara' in Winand M. Callewaert (ed.), Early Hind̄ devotional literature in current research ((Orientalia Lovaniensa Analecta, 8.) Leuven: Department Oriëntalistiek, 1980), 5-16; Mukund Lath, 'Bhajan as song: towards an oral stemma of Nāmadev's padas' in Monika Thiel-Horstmann (ed.), Bhakti in current research, 1979-1982 (Berlin: Dietrich Reimer Verlag, 1983), 225-36; Kenneth E. Bryant, 'The Fatehpur manuscript and the Sürasāgara critical edition project' in Thiel-Horstmann (ed.), Bhakti in current research, 37-52 and Winand M. Callewaert, 'Singers' repertoires in western India' in R. S. McGregor (ed.), Devotional literature in South Asia: current research, 1985-1988 ((University of Cambridge Oriental Publications, 46). Cambridge: Cambridge University Press, 1992), 29-35. For critical editions, see Winand M. Callewaert and Mukund Lath (ed.), The Hind̄̄ songs of Nāmdev ((Orientalia Lovaniensa Analecta, 29). Leuven: Departement Oriëntalistiek, 1989); Winand M. Callewaert and Bart Op de Beeck, Nirgun-Bhakti-Sagar; devotional Hindi literature. 2 vols. (Delhi: Manohar, 1991) and Winand M. Callewaert and Peter Friedlander, The life and works of Raidās (Delhi: Manohar, 1992).

Bulletin of SOAS, 64, 1 (2001), 34-58 C School of Oriental and African Studies, Printed in the United Kingdom. 
on the creation and maintenance of textual authority through commentary, both classical and later textual traditions show considerably less interest in techniques of textual criticism such as historicizing texts or comparing variant versions of a work. The only major exception to this in classical traditions is the occasional strategy by which 'commentaries cite alternative readings, providing, in effect, a kind of native critical edition.' ${ }^{4}$ Most other indigenous concern with texts per se has comprised the selection of one of a number of available recensions of a given work as its single authoritative version. The situation has largely been the same in the case of sacred texts, except where (largely Western) positivistic scholarship has attempted to reshape classical textual traditions. This general antipathy to the textual study of sacred documents is in contrast to the Islamic and Judeo-Christian traditions, both of which have shown a strong interest in the history of their sacred texts. This is not, of course, to imply that the wider conclusions of textual criticism were easily or quickly accepted by either of these groups. In the Islamic case, traditional schools of exegesis have recognized a number of ways of ' reading' the Quran characterized by different methods of interpreting the bare consonantal text of the scripture. More recent Western attempts to extend this type of analysis into a wider history of the compilation of the text have, however, been met with some hostility. ${ }^{5}$ A longer tradition of 'native' textual criticism exists within the Judeo-Christian tradition, in which the process of questioning the authorship of the Pentateuch began with the twelfth-century Spanish scholar Rabbi Abraham bin Ezra. Over the next seven centuries, works on textual criticism were routinely censored or suppressed by Church authorities, the celebrated nineteenth-century trial of William Smith by the Church of Scotland for denying the Mosaic authorship of the Pentateuch marking perhaps the last major intervention of this type. ${ }^{6}$ Although the Catholic Church was rather late in formally sanctioning textual scholarship in 1943, 'Protestant, Catholic and Jewish clergy have now been learning, and teaching, this subject for over a century and have managed to reconcile it with their beliefs and traditions.' 7 Indeed, the majority of textual scholars have been members of the clergy and scholarly analysis of the history of the Old and New Testaments 'is referred to in almost any standard introduction to the Old or New Testament, in hundreds of commentaries on the Bible, and most college and seminary courses on the Bible.'8

As in the Islamic and Judeo-Christian cases, the textual study of the Adi Granth has generated a great deal of initial hostility and resistance. Since this has yet to be overcome, textual study is still a long way from being assimilated into either mainstream writing on Sikhism or Sikh religious discourse. While the earliest debates on the text of the Adi Granth in the early decades of the twentieth century rose from issues connected with the printing of the text, they

\footnotetext{
${ }^{4}$ Wendy Doniger and Brian K. Smith (tr.), The laws of Manu (New Delhi: Penguin, 1991), lxxii. A Sikh example is provided by a late nineteenth-century commentary on a line of Kabīr in Sorathi $r \bar{a} g a$ in the Adi Granth (654) for which two readings exist in manuscript traditions $(\bar{A} d i$

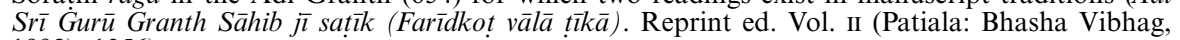
1992), 1356)

${ }^{5}$ For this type of reaction, see, for example, Labib As-Said, The recited Koran: a history of the first recorded version. Trans. and adapted by Bernard Weiss, M. A. Rauf and Morroe Berger (Princeton, NJ: Darwin Press, 1975).

${ }^{6}$ Richard Eliot Friedman, Who wrote the Bible? (New York: Harper and Row, 1987), 19-22. Smith, an editor of the Encyclopedia Britannica, was subsequently expelled from his chair of Old Testament studies.

7 ibid., 27, 243

8 ibid., $15,13$.
} 
quickly degenerated into harsh invective and, occasionally, outright hostility. ${ }^{9}$ G. B. Singh, the author of a 1944 study of Adi Granth manuscripts, is said to have been beaten with an old shoe in the streets of pre-Partition Lahore for the acidic remarks contained in his book. For most of the twentieth century, Sikh scholarship (with a few exceptions) has steered clear of discussion of the manuscript traditions of the Adi Granth, and when the history of the text was discussed it was usually in the context of disputes over the printing of the authorized text of the scripture. Over the past decade, the tempo of work on early Sikh scriptural traditions has accelerated; so too has the nature and scope of opposition to that work. Two scholars, Piar Singh and Pashaura Singh, were excommunicated from the community and given symbolic religious punishment at the Akal Takht in Amritsar in 1993 and 1994 respectively, ostensibly for having questioned the traditional account of the compilation of the Adi Granth. ${ }^{10}$ As a result, scholarly work on the scriptures became a focus of public attention, and calls were made within the community to ban all such work. Not unexpectedly, the resulting climate did little to stimulate or encourage academic debate: in many ways, textual work on the Sikh scriptures has remained precisely where it was at its formal beginnings in the 1940s. This article briefly examines previous work on Adi Granth textual traditions before attempting to identify new areas for inquiry and to connect textual study with a wider perspective on the history of the early Sikh Panth.

Sikh tradition records that the Adi Granth was dictated by the fifth Guru, Guru Arjan, to his disciple and maternal uncle Bhāì Gurdās at Rāmsar near Amritsar during the years 1603-4. ${ }^{11}$ Early traditions state that Guru Arjan had two motives for compiling the volume: to differentiate the Sikh Panth from Hindus and Muslims and to counter the oral circulation of spurious Mīnā compositions bearing the chhāpa (poetic signature) 'Nanak'. ${ }^{12}$ In order to have as complete a collection of the $b \bar{a} n \bar{l}^{13}$ as possible, Guru Arjan decided to approach Mohan, the son of the Guru Amardas, who had in his possession pothis (volumes) containing the compositions of the first three Gurus. After much persuasion, Mohan was convinced to part with the volumes, which

${ }^{9}$ For a discussion, see Nripinder Singh, The Sikh moral tradition (New Delhi: Manohar, 1991), 225-36.

${ }_{10}$ For a first-hand account of the first case, see Piar Singh, Gatha Sri Adi Granth and the controversy (Michigan: Anant Education and Rural Development Foundation, 1996); for a firsthand account of the second case, see Pashaura Singh, 'Recent trends and prospects in Sikh studies', Studies in religion 27 (1998), 407-25. Both cases are referred to in W. H. McLeod, 'Discord in the Sikh Panth', Journal of the American Oriental Society 119/3 (1999), 381-9 and some reference is made to Pashaura Singh in W. H. McLeod, "Cries of outrage: history versus tradition in the study of the Sikh community', South Asia Research 14/2 (Autumn 1994), 121-35.

${ }^{11}$ Sarūpdās Bhallā, Mahima a prakāsha, ed. Gobind Singh Lamba and Khazan Singh. Vol. II (Patiala: Bhasha Vibhag, 1971), 358-80; Santokh Singh, Shrī Gura pratāpa sūraja grantha. 4th ed. Vol. vI, ed. Bhai Vir Singh (Amritsar: Khalsa Samachar, 1963). 2038-59 (rāsi 3.32-5), 2073-2145 (rāsi 3.39-50); Bhagat Singh, Gurabilāsa Pātashāhī-6 krit Bhagat Singh, ed. Gurmukh Singh (Patiala: Punjabi University, 1997), 89-161 (adhyāyas 4 and 5: 1-43). The earliest version of the tradition, dated $1826 \mathrm{VS} / 1769$, is Kesar Singh Chhibbar, Bhā̄ Kesar Singh Chhibbar krit

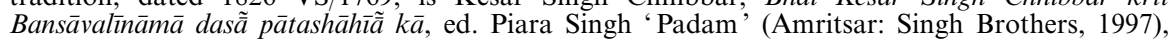
245 (charana 14: 266). Chhibbar gives the year of the text's composition as 1658 VS/1601-02.

${ }^{12}$ See The Chaupa Singh Rahit-Nama, ed. W. H. McLeod (Otago: University of Dunedin Press, 1987), 92 and Kesar Singh Chhibbar, Bansāuvalīnamāa, 80-1 (charanas 5: 87-8, 92-3). For the Mīnās, see Jeevan Deol, 'The Mīnās and their literature', Journal of the American Oriental Society 118 (1998), 172-84.

${ }_{13}$ The term refers to the works of a single author in the Granth or to the body of compositions in the Granth as a whole. 
became known as the Goindvāl pothīs after his place of residence. ${ }^{14}$ The account of the compilation of the Granth in Sarūpdās Bhallà's Mahimā prakāsha (1776) notes that 'other bāniss were requested from wherever they were. ${ }^{15}$ Traditionally, these other sources have numbered three: a Năth-influenced text called the Präna sangalī said to have been recovered from Singhaldīp (often identified with modern Sri Lanka) and eventually not included in the Granth, individual shabads (compositions) recorded by devotees, and a volume belonging to one Bhāī Bakhtā Arorāa ${ }^{16}$ After collecting all the possible bān̄is together, tradition continues, Guru Arjan recited them to Bhāî Gurdās, who distinguished between the authentic and the spurious texts. The compilation of the text then proceeded sequentially from $r \bar{a} g a$ to $r \bar{a} g a$. The manuscript prepared by Guru Arjan is believed to be the volume presently in the possession of the Soḍhī family of Kartārpur near Jalandhar. ${ }^{17}$

After Guru Arjan's text was completed, tradition records that a Sikh named Banno requested permission to take the volume to his own village of Khārā Māngat in the Gondal bār near the city of Gujrat (now in Pakistan). ${ }^{18}$ After much deliberation, the Guru decided to allow Banno to take the text to his village for one night only. As Banno wanted to make a copy of the text for himself, he travelled to his destination in stages, employing a team of scribes to copy the manuscript at each of his many halts. According to Mahimā prakāsha:

Because the text was written by many hands, some shabads were written out of place. This text is called the 'Khärā recension' to distinguish it from the 'Gurdās recension'. The book was completed on the way and Banno came to see the Guru. The Guru was pleased to see [the volume] and authorized it with his signature. ${ }^{19}$

Like most other nineteenth-century sources, the Gurabilāsa insists that Banno added extra texts to his volume.

The book was finished in Lahore. [Banno] got his text from [his scribes] and wrote in some extra bāṇ̄. He expanded Sūr's composition in Sāranga, writing the whole of 'chhädi mana hari bimukhana ko sanga' where there was one line. He wrote Mìrābāì's 'mana hamārā bādhio rī mā̄', and the

\footnotetext{
${ }^{14}$ For a description of one of the two extant volumes said to be the Goindvāl pothīs, see

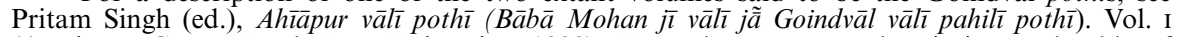
(Amritsar: Guru Nanak Dev University, 1998). For a less accurate description and table of contents for both volumes, see Gurinder Singh Mann, The Goindval pothis: the earliest extant source of the Sikh canon ((Harvard Oriental Series, 51). Cambridge, MA: Harvard University Press, 1996).

${ }_{15}^{15}$ Sarūpdās Bhallā, Mahimā prakāsha, 361.

${ }^{16}$ Giānī Giān Singh, Tavārīkh Gurū Khălsā. Vol. I. Reprint ed. (Patiala: Bhasha Vibhag, 1993), 417-18. For an edition of the Prāna sañgat̄, see Jagjīt Singh Khānpurī (ed.), Prāna sarigal̄̄ (Patiala: Punjabi University, 1991). Bhāī Bakhtā's text is said to have been the manuscript kept at the dharamsālā of Hakīm Būtā Singh in Rawalpindi before 1947 (Giānī Giān Singh, Tavārīkh Gurū Khälsā , 417 note +). The manuscript was taken to Delhi in 1947 but its present whereabouts are unknown. The text has been described in G. B. Singh, Srī Gurū Granth Sāhib dī̃̃ prāchīn bīr (Lahore: Modern Publications, 1944), 205-15 and Piar Singh, Gäthā Srī Ādi Granth (Prāchīn bìi te pothī $\tilde{a}$ de $\bar{a} d h \bar{a} r$ te) (Amritsar: Guru Nanak Dev University, 1991), 130-4. For an edition of one of the texts in the manuscript, see Narindar Kaur Bhātīā (ed.), Srī Satigurū jī de muhã dĩ $\tilde{a}$ sākhī $\tilde{\bar{a}}$ (Amritsar: the editor, 1978).

${ }^{17}$ For a published description of the Kartārpur manuscript, see Bhāī Jodh Singh, Srī Kartārpuri bìr de darshan (Patiala: Punjabi University, 1968).

${ }^{18}$ For the story of Banno, see: Sarūpdās Bhallā, Mahimā prakāsha, 372-4; Santokh Singh, Gura pratāpa sūraja, 2136-40 (rāsi 3.49.33-55; 3.50.1-2); Bhagat Singh, Gurabilāsa, 149-51 (adhyāya 4: 395-408).

${ }_{19}$ Sarūpdās Bhallā, Mahimā prakāsha, 373. According to Bhagat Singh's Gurabilāsa Pātashāhī Chhevĩ (c. 1834-44) and Santokh Singh's Gura pratāpa sūraja (1844), though, the Guru gave Banno the text so he could take it to Lahore for binding.
} 
saloka 'jita dari lakha muhammadā'. He wrote the sixteen salokas of ' $b \bar{a} \bar{\imath}$ $\bar{a}$ tisa au $\bar{a} b a$ ', and the beautiful 'Ratanamālā'. He wrote the story of Rājā Shivnābh and the Rāgamāla $\ldots$.

According to this version, when he returned to Amritsar with both volumes, Bhāī Banno found that Guru Arjan would not accept his copy. ${ }^{20}$

Texts traditionally grouped in the Banno recension, which appear to comprise the majority of extant manuscripts of the Adi Granth, ${ }^{21}$ are characterized by the presence of a number of compositions not in the printed recension of the Adi Granth. The additional texts are: three long compositions attributed to Guru Nanak ('jita dari lakha muhammadā', ' 'bā̄ àtisa au āba', and the Ratanamāla $)$ at the end of the text; a short prose text called Hakīkata rāha mukāma Rāje Sivanābha kī (which purports to tell the route to Rājā Shivnābh's kingdom in Singhaldīp) at the end of the text; a composition by Mīābāi in Mārū rāga; 24 lines of a chhanta by Guru Arjan in Rāmakalī rāga ('rana jhuñjhanara $\bar{a} \bar{a} u$ sakh $\bar{\imath}^{\prime}$ ) where the printed text has only two; an extra composition of Kabīr in Sorathi rāga ('avadhū so joḡ gura merā'), and a full poem by Sūrdās in Sāranga rāga where the printed text has only one line. ${ }^{22}$ The manuscript said to be the original Banno text, though, has had its date of writing altered from $1699 \mathrm{VS} / 1642$ to $1659 \mathrm{VS} / 1602$ and has had the Sūrdās and Rāmakalī compositions added in another hand. ${ }^{23}$

The textual tradition of the Adi Granth that forms the basis of the modern printed text is the Damdamā or Damdamī recension. According to Giānī Giān Singh's nineteenth-century version of the tradition, Gobind Singh dictated from memory the contents of Guru Arjan's text plus the compositions of the ninth Guru, Guru Tegh Bahadur, to his follower Bhā̄ Manī Singh at Damdamā in the Mālvā region of Punjab in 1706; he had been forced to do this by the refusal of Dhïrmal, the custodian of Guru Arjan's manuscript, to loan him the volume. The resulting text was nevertheless the same as the Kartārpur text, except for what Giān Singh calls 'many differences of spelling known to wise Sikhs.' The volume is said to have been the first to incorporate the compositions of Guru Tegh Bahadur. ${ }^{24}$ Some later commentators claim that the changes

${ }^{20}$ Bhagat Singh, Gurabilāsa, 150-1 (adhyāya 4: 402-5), 90 (adhyāya 4: 408). For a published description of the manuscript (now in Kanpur, Uttar Pradesh) said to be Bhā̄ Banno's original, see Pritam Singh, 'Bhāī Banno's copy of the Sikh Scripture', Journal of Sikh Studies 11 (1984), 106-7, 104.

${ }^{21}$ W. H. McLeod, 'The Sikh scriptures: some issues', Sikh studies: comparative perspectives on a changing tradition, ed. Mark Juergensmeyer and N. Gerald Barrier (Berkeley: Graduate Theological Union, 1979), 101.

${ }^{22}$ For a text and discussion of the story of Rājā Shivnābh, see W. H. McLeod, 'Hakikat Rah Mukam Raje Sivanabh ki' Proceedings: Punjab History Conference (1969) (Patiala: Punjabi University, 1970), 96-105. The Rāmakal̄ text is Rāmakalī chhanta M5 5 (Adi Granth, 927); for a text of the 24 lines found in Banno manuscripts, see Pashaura Singh, 'Guru Arjan's Rāmakalī hymn: the central issue in the Kartarpur-Banno debate', Journal of the American Oriental Society 116 (1996), 725-6. The Kabīr text in Sorathi rāga corresponds to Shukdev Singh (ed.), Kabīra bījaka (Allahabad: Nīlābh Prakāshan, 1972), 120. The Mīrābāī pada does not appear in any of the printed editions of Mīrābāì's works based on Rajasthani sources alone; it is, however, attributed to Sūrdās in the Sūrasāgara; see Jagannāthdās 'Ratnākar' et al. (ed.), Sūrasāgara. Vol. II (Kāshī: Nāgarī Prachārin̄ī Sabhā, 1951), 1375 (pada 3903). For a discussion of the Sūrdās text, see Jeevan Deol, 'Sūrdās: poet and text in the Sikh tradition', Bulletin of the School of Oriental and African Studies 63/2 (2000), 169-93.

${ }^{23}$ Pritam Singh, 'Bhāi Banno's copy', 106-7, 104. The addition of the Sūrdās and Rāmakalī compositions is in agreement with the widespread eighteenth-century trend of changing manuscripts of other textual traditions into Banno texts as the popularity of the recension spread; see Pashaura Singh, 'The text and meaning of the Adi Granth' (Ph.D. thesis, University of Toronto, 1991), 59.

${ }^{24}$ For the story, see: Giānī Giān Singh, Srī Gurū pantha prakāsha (Patiala: Bhasha Vibhag, 1971), 318-19. According to the earliest eighteenth-century version of the story, Dhìrmal's refusal to give the Kartārpur text to Guru Gobind Singh caused him to compose orally the text of the Samundra sāgara grantha, which contained his own compositions (Kesar Singh Chhibbar, Bansāvalīnàmā, 159-60 (charana 10: 376-81)). Chhibbar does not give a date for the event, which is preceded by an episode dated $1757 \mathrm{VS} / 1700-1$ and followed by one dated 1755 VS/1698-99. 
made by Guru Gobind Singh included the alteration of the word khulase to khālase in a shabad by Kabīr in Sorathi rāga. ${ }^{25}$ Nineteenth-century tradition states that the manuscript compiled at Damdamā was the same volume that was invested with the Guruship by Gobind Singh upon his death at Nānder in Maharashtra in 1708. According to Giānī Giān Singh, the Khalsa lost the text to attacking Afghans in a battle near the village of Kup Rahịrā in Mālvā in 1762; from there, the text was supposedly taken to Kabul, where it was eventually deposited in 'the big dharamsāla' ${ }^{, 26}$ No one has ever located it there. ${ }^{27}$

The traditional framework enumerated above has largely provided the basis for twentieth-century scholarship on the Adi Granth. Much energy has been spent on proving or disproving the authenticity of the Kartārpur and Banno manuscripts and on arguing textual issues such as the proper position of the invocations in the text and the authenticity of the Rágamāla listing of rāgas that concludes the volume. Until very recently, though, the idea that the transmission of the $b \bar{a} n \bar{\imath}$ was a linear process that began with a single exemplar (either Kartārpur or Banno), and then diversified into separate textual strands, has remained largely unchallenged. At the same time, a new recension has been added to the textual repertoire, known as the 'Lahore recension' because its earliest exemplar dated $1667 \mathrm{VS} / 1610-11$ was found at a shrine in Lahore. ${ }^{28}$ The recension is characterized by the presence of an extra composition each of Nāmdev and Trilochan, a different arrangement of the ending portions of the text ${ }^{29}$ without the additional material of the Banno recension, and different headings on the 22 varas in the text. Other individual manuscripts have also been introduced into the textual debate. The two major shifts in the traditional narrative in the twentieth century were both temporal, the first assigning the responsibility for collecting the compositions of the bhagats to Guru Nanak and the second shifting the period of the compilation of the Damdamì recension

The mid-eighteenth century rahitnāmā attributed to Chaupā Singh places three events between Maghar 1735 VS/November 1678 and 1737 VS/1680-81: Dhirmal's refusal to lend the Granth, the composition of the Samundra sāgara grantha and the composition of another volume entitled Utāra lìlā [Avatāra lìlā] (McLeod (ed.), The Chaupa Singh rahit-nama, 82).

${ }^{25}$ The shabad is Sorathi Kabīr 3 (Adi Granth, 654-5). Although he does not himself accept the claim, Kāhn Singh Nābhā notes that 'many writers' state that Guru Gobind Singh changed the word (Guru shabad ratnākar mahān kosh. Reprint ed. (Delhi: National Bookshop, 1990), 374, $\mathrm{n} *$ ). Seventeenth-century manuscripts of the Adi Granth usually do have the reading khulāse rather than the Damdami recension's khālase, although a Banno manuscript dated 1723 VS/1666 and another Banno text dated $1748 \mathrm{VS} / 1691$ containing the compositions of the ninth Guru as an integral part of the text both have the reading supposedly introduced for the first time into the Damdamī recension (Punjab State Archives, Patiala Ms 341 and Panjab University, Chandigarh MS 1189). The reading khuläse appears in a lithographed Banno text printed at the Giān Press, Gujranwala in 1938 VS/1882 (India Office, London Panj H21, 540). For reference to a nineteenthcentury commentary that acknowledges the presence of both readings, see n. 3 above.

${ }_{26}^{6}$ Giānī Giān Singh, Pantha prakāsha, 319. See also Ratan Singh Bhangū, Prāachīna Pantha prakāsha, ed. Bhā̄ Vir Singh, 4th ed. (Amritsar: Khalsa Samachar, 1962), 369-70. Writing in 1841, Bhangu does not elaborate on the fate of the manuscript after the battle except to say that the volume and its defenders were surrounded by the Afghans.

${ }^{27}$ For an account of a 1952 research trip to Afghanistan which investigated Adi Granth manuscripts, see Ganda Singh, Afghānistān dā safar. 3rd printing (Delhi: Parkāsh and Sons, 1960).

${ }^{28}$ For the Lahore manuscript, see Svāmī Harinām Dās Udāsīn, Ādi Srī Gurū Granth Sāhib $\bar{j}$ dĩã purātani bìr ã te vichār. 2 vols. (Kapurthala: Ramesh Chandra Sūrī, 1969-70), vol. I, 106-8, vol. II, 76-7; Piara Singh 'Padam,'Srī Gurū Granth Prakāsh. 2nd ed. (Patiala: the author, 1990), 101; and Shamsher Singh 'Ashok', Panjābì hatth likhtã dī süchī. 2 vols. (Patiala: Bhasha Vibhag, 1963), vol. II, 166. The volume was in the Sikh Reference Library in the Golden Temple complex in Amritsar. For the fate of the library, see $\mathrm{n} 46$ below.

${ }^{29}$ The order of compositions after chaubole is: saloka vārā te vadhīka, mundāvan̄ī (with saloka), savayye srī mukhavāka M5, savayyās of the Bhatțs, salokas of Kabīr and salokias of Farīd. In some manuscripts usually included in the recension, the compositions after mundāvan̄ occur in the following order: salokas of Kabīr, salokas of Farīd, savayye srì mukhavāka M5 and savayyās of the Bhatts. 
from 1706 to the 1670 s on the basis of manuscript evidence. ${ }^{30}$ The first author to suggest a change in the date of the compilation of the Damdami recension was G. B. Singh, who in 1944 discovered a manuscript dated 1732 VS/1675 whose text was largely identical to the Damdami recension. Unwilling to abandon entirely the traditional name of the recension, G. B. Singh claimed that the 1675 text must have been compiled at the command of Guru Tegh Bahadur at a place called Damdamā in the town of Anandpur. ${ }^{31}$ His argument was later extended with further evidence of pre-1706 manuscripts by Haribhajan Singh, who modified G. B. Singh's argument to claim that it was Guru Gobind Singh who first dictated a new recension of the Granth at Damdamā in Anandpur before repeating the feat at Damdamā in Mālvā in $1706 .^{32}$ The final temporal shift in the traditional narrative of the compilation of the Adi Granth - one that did not receive much recognition at the timewas Giānī Gurditt Singh's contention that the Goindvāl pothīs indicate that it was Guru Amardas who put the compositions of the first three Gurus in their present order and collected the compositions of figures such as Kabīr and Nāmdev. ${ }^{33}$ This argument has recently been repeated by Gurinder Mann. ${ }^{34}$ Despite having been labelled 'provocative, contentious, controversial' by his critics, the work of Pashaura Singh also fits into the traditional linear framework. ${ }^{35}$ Pashaura Singh argues that the scriptural text evolved through the Goindval pothīs and a previously unknown text (Guru Nanak Dev University, Amritsar MS 1245) to the Kartārpur pothī and from there split into the Kartārpur, Banno and Lahore recensions. Despite the fact that the Guru Nanak Dev University manuscript shows numerous signs of having been independently compiled from oral singing traditions, he takes it to be Guru Arjan's preliminary 'draft' of the Adi Granth intermediate on the traditional 'family tree' of manuscripts to the Goindvāl and Kartārpur texts. ${ }^{36}$ The argument that the $b \bar{a} n \bar{l}$ was edited at each of these stages infuriated some in the Sikh community, and Pashaura Singh was summoned to the Akal Takht in Amritsar for religious punishment in 1994.

While the general tone of Adi Granth scholarship has, therefore, remained largely traditional, there have been a number of authors-including Piara Singh 'Padam', Svāmī Harinām Dās Udāsīn, Shamsher Singh 'Ashok' and a panel appointed by the Sikh regulatory body in Punjab, the Shiromani Gurdwara Prabandhak Committee - who have suggested that the manuscript tradition be used to correct the hitherto inviolable printed text of the Adi Granth. ${ }^{37}$ The most major departure from traditional scholarship to date was

\footnotetext{
${ }^{30}$ For an explication of the first view, see Sāhib Singh, Ā di bīr bāre (Amritsar: Singh Brothers, 1970). The bhagats are figures such as Kab̄̄r, Nāmdev, Ravidās, Trilochan, Jaidev, Sadhnā, Sain, Pìpā and Dhannā.

${ }^{31}$ Prāchīn bìr $\overline{\tilde{a}}, 215,76-9$. The manuscript was found in Dhaka.

${ }^{32}$ Haribhajan Singh, Gurbān̄ì sampādan nirṇai (Chandigarh: Satinām Prakāshan, 1981), 12, 135-49.

${ }^{33}$ Giānì Gurditt Singh, Itihās Srī Gurū Granth Sāhib (Bhagat Bān̄̄ Bhāg) (Chandigarh: Sikh Sahitt Sansthan), 481-584.

${ }^{34}$ The Goindval Pothis.

${ }^{35}$ For an example of the stigmatization of Pashaura Singh, see Kuldeep Singh, 'Pashaura Singh: provocative, contentious, controversial', in Bachittar Singh Giani, Planned attack, 235-44. ${ }^{36}$ Pashaura Singh. 'The text and meaning' and 'An early Sikh scriptural tradition: the Guru Nanak Dev University manuscript 1245', International Journal of Punjab Studies $1 / 2$ (JulyDecember 1994), 197-222. For a similar instance of what seems to be an independent compilation being taken as a draft for almost the same reasons, see Giānī Mahã Singh, 'Bāhovāl vālī Pothī Sāhib: Pavittar Ādi Bị̣̣ de samkālīn ikk purātan pothī', Kherāa 1/4 (March 1980), Punjabi section, 13-16.

${ }^{37}$ Piara Singh 'Padam', Srī Gurū Granth Prakāsh, 82, 95-6; Svāmī Harinām Dās Udāsīn, Purātani bīrã̃ ; Shamsher Singh'Ashok', 'Srī Àdi Granth te Dasam Granth dīã bīrã̃', Parkh 1 (1971), 33-4; Sardār Randhīr Singh, Giānī Kundan Singh and Bhāī Giān Singh 'Nihang' (ed.), Srī Gurū Granth Sāhib jì dĩã santhā-sainchīã ate purātan hatth likhit pāvan bīrä̃ de paraspar pāth-

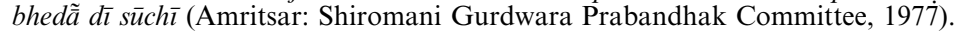


made by Piar Singh in his book Gātha Srī A di Granth, which was withdrawn from sale under the instructions of religious authorities in late 1992 and has not, as a result, enjoyed wide circulation. Piar Singh argues that the compilation of the Granth was a gradual process that began before the period of Guru Arjan and continued after his death, with separate rāga sections probably being circulated independently among early Sikh congregations. ${ }^{38}$ Unlike earlier authors, Piar Singh does not postulate a distinct recompilation of the scripture by Guru Tegh Bahadur or Guru Gobind Singh, either in Anandpur or in 1706; instead, he argues that the granting of Guruship to the Granth on Guru Gobind Singh's death in 1708 engendered a new concern for textual accuracy. ${ }^{39}$ Piar Singh groups extant Adi Granth manuscripts into seven broad recensions based on their textual features, noting at the same time that although the Kartārpur and Banno recensions are related, the Banno manuscript cannot be a copy of the Kartārpur text due to the large number of textual variants between the two. He further argues that since the headings of Banno manuscripts differ a great deal among themselves, the evolution of the Banno recension cannot be completely linear either. ${ }^{40}$ Piar Singh's suggestions that the printed text of the Adi Granth contains errors and excludes some of the Gurus' compositions, that the Kartārpur manuscript represents an early collection which was later transformed by its custodians into what they felt Bhā̄ Gurdās's text should have been, and that the text of the mülamantara ${ }^{41}$ evolved over time attracted particular ire and seem to have been the proximate causes of the banning of the book. He was summoned to the Akāl Takht for religious punishment in 1993.

In addition to the problems created by religious opposition to textual work, a number of practical difficulties plague Adi Granth scholarship. The fact that many of the most important manuscripts are in private possession very often means that they are not available to the researcher: Giānī Gurditt Singh, for one, has complained of the many years of difficulty he encountered in trying to obtain access to the Goindvāl volumes. ${ }^{42}$ Additionally, physical access to many texts is often denied to all but initiated amritdhār $\bar{l}$ Sikhs or shrine functionaries, and objections are often made by some sections of the community to the photographing of manuscripts. ${ }^{43}$ More serious than these difficulties of access, though, has been the wholesale and often wilful destruction of Adi Granth manuscripts. According to tradition, many Adi Granth manuscripts were destroyed during the Mughal and Afghān persecutions of the mideighteenth century. ${ }^{44}$ In the twentieth century, a number of manuscripts seem to have been destroyed or spirited away by shrine custodians during the Akali agitations for the control of gurdwārās during the 1920s. Far more serious, though, was the Partition of 1947, during which innumerable manuscripts were destroyed or left behind to an uncertain fate by fleeing Sikhs and Hindus. Fortunately, a number of manuscripts were brought to India, where they formed the backbone of the Sikh Reference Library in the Golden Temple complex in Amritsar. Published estimates of the number of Adi Granth

${ }^{38}$ Gāthā, 431, 437-8.

39 ibid., 472 .

40 ibid., 438-47, 468.

${ }^{41}$ The invocation found at the beginning of the text and each of its major sections

${ }^{42}$ Giānī Gurditt Singh, Itihās, 569.

43 One observer has noted that 'a few years ago' the efforts of a 'noted Sikh scholar' to photograph the Kartārpur manuscript were thwarted by such objections; see C. H. Loehlin,

Textual criticism of the Kartārpur Granth', in Juergensmeyer and Barrier, Sikh Studies, 117.

${ }_{44}$ According to Ratan Singh Bhangū, Dìvān Lakhpat Rāi threw Granths and pothis into rivers as part of his campaign to destroy the Sikhs during the years 1746-47, see Ratan Singh Bhangū, Prāchīna pantha prakāsha, 322. 
manuscripts held in this collection range from 500 to as many as $1,500 .{ }^{45}$ The entire library was reportedly reduced to ashes during the Indian Army's attack on the complex in June $1984 .{ }^{46}$ In addition to the enormous losses suffered in 1984 and 1947, the Sikh scriptural heritage has been subject to wilful destruction by Sikh bodies as well: the Shiromani Gurdwara Prabandhak Committee has regularly carried out the ceremonial 'cremation' of old manuscripts at Goindvāl and reportedly disposed of some of the oldest manuscripts in the Sikh Reference Library's collection in the 1960s on the grounds of their age. ${ }^{47}$ In such difficult circumstances, the task of constructing a properly detailed picture of the early history of Adi Granth manuscripts and, through them, of the early Panth, is a very difficult one indeed.

\section{II}

As recent scholarship has begun to show, there is much about pre-modern manuscripts of the $b \bar{a} n \bar{\imath}$ that is not accounted for in the dominant linear narrative of the compilation of the Granth. Perhaps the least discussed aspect of these manuscripts is evidence revealing that a number of attempts were made to compile the $b \bar{a} n \bar{l}$. For example, modern writing ignores evidence that early traditions assigned a role in the collection of the $b \bar{a} n \bar{l}$ to the fourth Guru, Guru Ramdas: manuscripts grouped in the Kartārpur and Banno recensions state in their indices that Japu (the first composition in the text) was copied from a manuscript written by Guru Ramdas. The tradition seems to have continued into the nineteenth century, since at least one illustrated nineteenthcentury manuscript that depicts the ten Gurus on its opening folios shows both the fourth and the fifth Gurus with prominently displayed written volumes. ${ }^{48}$ It also appears that a number of early attempts independent of Guru Arjan's were made to compile the bānī. A no longer extant manuscript at Gurū Harsahāî, district Ferozepur, and the two Goindvāl volumes appear to have been compiled before Guru Arjan's Adi Granth, while Guru Nanak Dev University, Amritsar MS 1245 and the Bāhovāl pothī seem to have been compiled after $1604 .^{49}$ All of these manuscripts display the types of variant readings to be expected from different oral repertoires of the $b \bar{a} n \bar{\imath} \bar{l}$, including

\footnotetext{
${ }^{45}$ Harinām Dās Udāsīn, Purātani bīrãa 95; Sardar Raṇdhīr Singh, et al., Pāth-bhedã dī sūchī, $\bar{\imath} \bar{\imath}$; Haribhajan Singh, Gurbān̄ sampādan nirnai, 116. Partial catalogues of the collection were

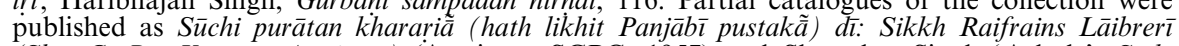
(Shro.Gu.Pra.Kameț̄̄, Amritsar) (Amritsar: SGPC, 1957) and Shamsher Singh 'Ashok', Sādā hatth-likhit Panjābì sāhitt (Amritsar: SGPC, 1968).

${ }^{46}$ Since the preparation of this paper, a number of reports have emerged in the Indian press suggesting that the contents of the library survived the attack: while initial reports implied that the library was intact and in Government custody, later reports referred to the return of five manuscripts and a number of other articles in October 1989 (see 'Sikh library books with CBI': Fernandes' Tribune online edition, 23 May 2000 and 'Badal writes to PM on scriptures seized by army', Tribune online edition, 6 June 2000). It is still unclear at this point whether the initial reports were correct in referring to the survival of the library or whether they actually meant to refer to the articles returned in 1989

${ }^{47}$ Ganda Singh, 'Sikh itihās dīã kujh-ku samassiāvã', Singh Sabhā patrikā 4/5 (August 1978), 39.

48 See National Museum, New Delhi, Paintings Department N.M. 59.155/2, a folio separated from N.M. 61.1006, a Damdamī Adi Granth manuscript written for Soḍh $\overline{1}$ Bhān Singh of Haranpur and completed in 1843-44. The folio has been published in Susan Stronge (ed.), The arts of the Sikh kingdoms (London: V \& A Publications, 1999), 12; B. N. Goswamy, Piety and splendour: Sikh heritage in art (New Delhi: National Museum, 2000), 50-1 and Karuna Goswamy, Kashmiri painting: assimilation and diffusion; production and patronage (Shimla: Indian Institute of Advanced Study, 1998), 153-4 (illustration between 132-3), where the identity of the manuscript has not been given.

${ }^{49}$ For a description of the Bāhovāl manuscript, see Giān̄i Mahã Singh, 'Bāhovāl vālī pothī sāhib' and Piar Singh, Gāthā, 120-9. The Bāhovāl pothī is presently at the Bhai Vir Singh Sahitya Sadan, New Delhi.
} 
variant readings, different numbers of lines in a composition, lines in an individual composition in a different order and individual compositions appearing in different rāgas in each repertoire. In particular, Guru Nanak Dev University MS 1245 may have been used for singing since each rāga section has been given a separate index. Other early manuscripts appear to be descended from variant scribal (if not oral) traditions as well: a manuscript from the village of Sāranke near Lahore dated 1728 VS/1671-72 displays scribal features distinct from those of the established textual recensions, and the Bhā Paindā manuscript from Rawalpindi appears to have been a mid- to late seventeenth century compilation of the $b \bar{a} n \bar{l}$ and other texts. ${ }^{50}$ It is not clear whether such alternative versions of the $\bar{b} \bar{a} n \bar{l}$ continued to be represented in later manuscripts, and it may well be that these collections and others formed the basis of 'families' of texts based in specific regions or used by specific groups. It seems, for example, that the Bāhovāl volume was from a village of that name situated 20 miles from the town of Phālīa in district Gujrat, ${ }^{51}$ an area which before 1947 was home to a number of old poth $\bar{\imath}$, including the text said to be the original Banno manuscript. ${ }^{52}$ Although most of these manuscripts are no longer extant, it is possible that some of them may have been descended from or influenced by the Bāhovāl volume and shared some of its readings. If this were indeed the case, we could expect that as the Adi Granth gained popularity such independent compositions and their descendants would have suffered a consequent decline in their fortunes.

The alternate oral repertoires of the Gurus' compositions that seem to have been preserved in some of these early pothis deserve serious study. It would seem from internal evidence provided by both these early manuscripts and the Adi Granth that a number of oral repertoires or ways of performing the $b \bar{a} n \bar{l}$ were in existence at the same time. The most salient example of this phenomenon in the printed Adi Granth is the presence of three variant versions of the Guru Nanak shabad 'so daru (tera) kehā'-one in the extended composition $J a p u$, one in the section of the text comprising the evening liturgy and one in $\bar{A} s \bar{a}$ ragga ${ }^{53}$ The first is part of a larger text intended for recitation, while the latter two are intended for singing and are characterized by a number of metrical alterations that lengthen the line; each version also has a number of minor variants. A similar instance appears in one of the Goindvāl poth $\overline{\mathrm{s}}$ presently at Jalandhar, in which the Kabīr shabad 'isu tana mana madhe madana chora' appears in two variant forms in Basant rāga, indicating that at least two repertoires of the works of the bhagats were available to the compiler of the volumes. ${ }^{54}$ In addition to the internal variations present within all the early manuscript traditions, there are also indications that the mode of performing the repertoire used to compile the Adi Granth may have differed from

\footnotetext{
${ }^{50}$ The Sāranke manuscript is now Guru Nanak Dev University, Amritsar MS 1229; for a published description, see Piar Singh, Gāthā, 302, 471-2. For the Bhāì Paindā manuscript, see n16 above.

${ }^{51}$ Giānī Mahã Singh ('Bāhovāl vālī', 14) states that the original owner of the manuscript was a Bedī from Bāhovāl, district Gujrat. Maps of the Gujrat area show that the only village of that name in the district is in tahsīl Phāliā. There were at least two other villages named Bāhovāl in undivided Punjab, one of which is six miles north of Gujrat in district Sialkot. Reference to Khālsā Darbār and British land records should solve the problem of the location of the village, since the Bedi custodians of the manuscript are said to have held a jāg $\bar{t} r$ there.

${ }_{52}$ For a published description of one of the manuscripts (from the village of Pindī Lālā), see Piar Singh, Gäthā, 309-12.

${ }_{53}$ Adi Granth, 6, 8-9, 347-8.

${ }^{54}$ I base these comments on my reading of a set of photographs of the poth $\bar{\imath}$ in the possession of Professor Pritam Singh of Patiala in July 1999. Mann's somewhat misleading account of the pothis' contents ignores the differences of reading between the two versions of the shabad and between the pothis' versions and the Adi Granth shabad (Mann, The Goindval Pothis, 97, 179 n91). The shabad is Adi Granth, 1194.
} 
that favoured by the compilers of the other pothis. One of the features which seems to indicate the existence of a distinct system of performance is the use in the Adi Granth of a system of gharas ('houses') within rāgas: the meaning of these ghara divisions has not been passed down in Sikh exegesis, but it seems likely that they would have had implications for the performance of rāgas or shabads. These ghara divisions are not present in the Goindvāl pothiss. Another feature is the presence in Mārū rāga in the Adi Granth of two shabads to which verses corresponding to the $u d g r \bar{a} h a^{55}$ of traditional prabandha compositions have been added: a saloka by Guru Arjan precedes the Guru Nanak composition 'bāba mai karamahina kūriāra' and another is given before the Guru Nanak composition 'jo mai bedana sā kisu $\bar{a} k h \bar{a} m \bar{a} \bar{l}$.' ${ }^{56}$ These udgrāhas do not appear in the Goindvāl poth $\bar{\imath}$ or in the Guru Nanak Dev University MS 1245 versions of these compositions. ${ }^{57}$ Again, this formal feature implies that the style of performance used in the repertoire that came to form the Adi Granth may have been different than the styles used in the repertoires represented in other early pothis.

A sustained investigation of early pothis of the traditional three 'preDamdamā' recensions may show that the manuscripts-and therefore the recensions themselves - are also descended from or influenced by independent compilations rather than a single source. In that case, we can expect to see both 'cross-fertilization' between various recensions over time and a decrease in the amount of variation both within and between recensions as standardization increases. The traditional 'family tree' of Adi Granth manuscripts would therefore be replaced by a biological model in which an initial proliferation of a number of unique texts would be followed by the continuation of only some textual families and the demise of others. Cross-fertilization between surviving recensions - and occasionally from recensions which became 'extinct' - would complicate the traditional ' family tree' of the Adi Granth recensions. ${ }^{58}$ During this process, one would expect the popularity of independent compilations of the $b \bar{a} n \bar{\imath}$ to disappear almost completely. If, on the other hand, extant early Adi Granth manuscripts are not in fact descended from

${ }^{55}$ According to thirteenth- and fifteenth-century treatises on musical theory, an udgrāha is a ' take-up' verse sung at the beginning of a composition (prabandha) but before the teka or dhruva refrain verse (the rahāu verse in the Adi Granth). The udgrāha is usually independent from the composition and in a different metre. For a thirteenth-century definition of the term, see S. Subrahmanya Sastri (ed.), Sañītaratnākara of Särnigadeva with Kalānidhi of Kallinātha and Sudhākara of Simhabhūpāla. Vol. II (Adyar Library Series, 43. Madras: Adyar Library, 1944), 188-90, 194; and for a definition from a text dated 1428, see Emmie te Nijenhuis (ed.), Sañgittaśiromani: a medieval handbook of Indian music (Leiden: E. J. Brill, 1992), 359. In the Adi Granth corpus, most shabads have their first verse (antarā) placed before the rahāu, presumably to substitute for an udgrāha.

${ }_{56}^{5}$ The first composition is Mārū M1 chaupade 1 (Adi Granth, 989) with Gūjarī vāra M5 saloka M5 1: 4 (Adi Granth, 518) as udgrāha; the second composition is Mārū M1 chaupade 5 (Adi Granth, 990) with Gūjarī vāra M5 saloka M5 2: 4 (Adi Granth, 518) as udgrāha. In both cases, the udgrăha is marked as 'saloku' and the prabandha as 'sabadu'. The shabad 'jo mai bedana sā kisu $\bar{a} k h \bar{a}$ mā̄' is attributed to Ravidās in Sāranga rāga in the Fatehpur manuscript from Rajasthan dated $1639 \mathrm{VS} / 1582$; for a facsimile of the manuscript page, see Gopal Narayan Bahura (ed.), The padas of Surdas (Maharaja Sawai Man Singh II Memorial Series, 6. Jaipur: Maharaja Sawai Man Singh Museum, 1982), 146.

${ }^{57}$ Mann, The Goindval Pothis, 182, 115-16; Pashaura, Singh, 'The text and meaning', 144-7. Neither author seems to understand that the salokas are functioning as udgrāhas, as a result of which neither realizes the implications of this addition to the shabads in the Adi Granth; Mann remarks that ' $[\mathrm{t}]$ he reason for such additions is unclear' (ibid., 182, n115).

${ }^{58}$ Compare the phylogenetic model recently deployed to classify manuscripts of a portion of Chaucer's Canterbury tales in Adrian C. Barbrook, Christopher J. Howe, Norman Blake and Peter Robinson, 'The phylogeny of The Canterbury tales', Nature 394 (27 August 1998), 839. According to the authors, "the principle of historical reconstruction [of texts] is similar to the computerized techniques used by evolutionary biologists to reconstruct phylogenetic trees of different organisms using sequence data'. 
different exemplars and are indeed branches of a single copying tradition, the extent of cross-fertilization between the different recensions on the traditional 'family tree' and the evidence of standardization both between and within the various traditions still deserve serious study. Early pothīs such as the Bāhovāl, Goindvāl and Guru Nanak Dev University MS 1245 texts would still represent independent oral and textual traditions that failed to proliferate in the ways that the traditional Adi Granth recensions did.

In addition to studying early independent compilations and Adi Granth manuscripts, it will be necessary to study hitherto largely ignored eighteenthand nineteenth-century manuscripts in order to understand more fully the cross-fertilization of the traditional recensions. Only then can we begin to determine both the time frame and the extent of the standardization of the various manuscript traditions of the Adi Granth and to answer the question of whether earlier variant texts continued to be copied until quite late or were quickly replaced by standard texts of the main recensions.

A case in point is the Damdamī recension, surprisingly little-studied despite its importance to Sikh tradition. Very little is known about the distribution and dates of extant Damdamī manuscripts, although there are dated texts from 1771-2 and 1798-9 that have the textual features associated with the recension. ${ }^{59}$ Many extant Damdami manuscripts are from the nineteenth century, although the majority of them are, by their very nature, undated: most nineteenth-century Damdamī manuscripts omit those features of most other types of Adi Granth texts that help to determine their dates of copying. ${ }^{60}$ The omission of these textual features would seem to be in order to emphasize the eternal nature of the Granth as Guru over the individuality of the particular copy. Whatever the date at which copies of the recension began to proliferate, though, during the nineteenth century the town of Damdama acquired a reputation as a scribal centre, with a particular style of Gurmukhī script popularized by writers trained or based at the bung $\bar{a} \mathbf{s}^{61}$ around the main Damdamā Sāhib shrine coming to be known as 'Damdamī script'. It may be that the scribes of Damdamā were responsible for an increase in the number of texts of the recension in circulation during the same period.

Since no work has been done on the diffusion of Damdamī manuscripts, it is impossible to suggest any more than that a picture of their distribution would tell us much about both the Adi Granth and the nature of the eighteenth- and nineteenth-century Panth. If, for example, most Damdamī manuscripts are found in Punjab, it may suggest that the recension initially enjoyed greater legitimacy or currency in Punjab; alternately, it may mean that after a certain point in time lines of religious authority were much more clearly drawn in Punjab than in the rest of north India, thus allowing the recension to spread more quickly there than elsewhere. Preliminary investigations seem to hint that at least in the case of some shrines outside Punjab, the Damdamī recension arrived late and in relatively small numbers: of 50 seventeenth- to nineteenth-century Adi Granth manuscripts at

\footnotetext{
${ }^{59}$ See, for example, Bhasha Vibhag, Patiala Ms 377 dated 1855 VS/1798-99 and MS 378 dated $1828 \mathrm{VS} / 1771-72$. The colophon of the second text, indicating that it has been written by Jit Singh and Daiāl Singh at the shrine Bāolī Sāhib in Goindvāl, is in a different pen and weaker ink than the rest of the manuscript. The manuscript differs from the printed Damdamī text in that it attributes the 54th of the salokas usually attributed to the ninth Guru to the tenth Guru Gobind Singh. Compare Pashaura Singh's suggestion that most Damdamī manuscripts date from the nineteenth century, 'The text and meaning', 84-6.

${ }^{60}$ The features are: an index notation indicating how many removes the text is from the Japu of Guru Ramdas, a chalitru jotī joti samāvana ka containing the death dates of the Gurus and a colophon indicating the date when the text was written.

${ }^{6}$ Buildings constructed in the vicinity of a major sacred shrine such as the Harimandir Sāhib in Amritsar to accommodate pilgrims which were also used as educational establishments.
} 
Takht Srī Harimandir Sāhib in Patna-one of the takhts or central shrines of Sikhism - only four are Damdamī texts. One of the four is dated 1959 VS/1902, and the other three appear to date from the nineteenth century. ${ }^{62}$ More work clearly needs to be done to establish the time frame of the adoption of the Damdamī recension at other centres in north India as well as at shrines in Punjab itself. At the same time, it must be recognized that the nature of most manuscript holdings ultimately precludes the possibility of any absolutely firm conclusions on the matter: most manuscripts in public collections are not provenanced and most shrine collections are either incomplete or no longer extant. This means that it will remain virtually impossible to determine with any certainty the social and geographical distribution of any of the main recensions of the Adi Granth.

In addition to the problem of the diffusion of Damdamin texts of the Granth, attention also needs to be focused on the ways in which the compositions of the ninth Guru Tegh Bahadur were preserved and transmitted, both before and after they were added to the text of the Granth. The earliest extant dated manuscript containing the works of Guru Tegh Bahadur as a part of the main text appears to be a Banno text dated $1736 \mathrm{VS} / 1679 .{ }^{63}$ In the case of manuscripts written before the addition of the ninth Guru's works to the Granth, the most obvious questions are how and when his works were added to the volumes. While some extant early manuscripts have not had the compositions added at all, most have had them added either on new folios or in the margins of the existing text. It is not, however, clear whether the texts were copied from written exemplars or come from oral sources. Similarly, it is not clear whether later texts containing the works of the ninth Guru descend from a single written exemplar or from a variety of sources. Detailed comparative work might yield hypotheses about relationships between various extant texts of Guru Tegh Bahadur's works, particularly as available manuscripts display a number of variant readings. The number of salokas attributed to Guru Tegh Bahadur in the manuscript tradition occasionally varies from the printed version's 57, and at least two manuscripts contain two padas in Sirī rāga attributed to Guru Tegh Bahadur. Seven salokas not present in the printed text are found in some manuscripts, including a transcribed Persian verse from the seventh-century author Shaikh Sa'dī's Būstān and its translation in Braj. Of these seven salokas, three are found in the 1679 manuscript and the others in eighteenth-century texts. ${ }^{64}$ Such variants indicate that the addition of the

\footnotetext{
${ }^{62}$ I base my count on a viewing of the manuscripts in November 1998. Of the remainder of the manuscripts, 34 are Banno texts, two are of the Lahore recension, eight are Lahore texts that have been converted into Banno texts, one is of a rare recension that records the $b \bar{a} n \bar{l}$ of each of the contributors to the Granth separately rather than in the usual rāga-wise arrangement, and one arranges the $b \bar{a} n \bar{l}$ as in the Banno recension but identifies the Gurus who contributed to the Granth with the rubric 'Pātashāh' ' rather than the more usual 'Mahalā'. In addition to the attrition to be expected in any such manuscript collection, the statements of shrine functionaries appear to indicate that the character of the Patna collection has been affected by two other factors: a number of old manuscripts may have been sent to Goindvāl for ceremonial 'cremation', and manuscripts from smaller shrines may have been sent to the Takht for safekeeping after the 1984 anti-Sikh riots in the city.

${ }^{63}$ Dr Balbir Singh Sahitya Kendra, acc. no 4982. A manuscript with the works of the ninth Guru as a part of the main text bearing the date $1731 \mathrm{VS} / 1674$ is extant, but it is quite clearly a late eighteenth- or early nineteenth-century copy of an earlier original (Panjab University, Chandigarh Ms 1192). The Chandigarh manuscript contains a forged nissana (scriptural quotation in the hand of the Guru) attributed to Guru Tegh Bahadur that has quite clearly been traced over blue marking pencil, which is still visible at points. G. B. Singh describes a manuscript at Dhaka dated $1732 \mathrm{VS} / 1675$ with the ninth Guru's works at appropriate places in the text, but it is not clear whether it is still extant (Prāchīn bìr $\tilde{\tilde{a}}, 215-34)$.

${ }^{64}$ For details, see Jeevan Deol, "Non-canonical compositions attributed to the seventh and ninth Sikh Gurus', Journal of the American Oriental Society (forthcoming).
} 
ninth Guru's compositions to the Adi Granth may have been a more complex process than we currently imagine. Clearly much work needs to be done before we can begin to understand the ways in which the compositions of Guru Tegh Bahadur were transmitted and preserved during the seventeenth and eighteenth centuries.

Despite the existence of multiple recensions of the Granth at the beginning of the manuscript tradition, there seems to have been a very strong concern within the Panth for textual authority and accuracy from at least the midseventeenth century onward. A text completed in $1716 \mathrm{VS} / 1659$ notes that it has been compared with 'the fifth Guru's granth', ${ }^{65}$ while a manuscript in Patna dated 1748 VS/1691-92 supplements a reference to the fifth Guru's manuscript with an additional source of authority:

This granth is a copy of Fatehchand's granth, which is a copy of the Pushkar granth. The Pushkar granth has been corrected against the 'great granth' (vadda granth) that the fifth Guru had written by Gurdās. A granth corrected against that one becomes correct (sudh); if you still want to correct your text, then compare it to Jagnā Brahman's granth. Jagnā Brahman's granth is more correct than others, and the Pushkar granth has been corrected against Jagnā's text. ${ }^{66}$

This note indicates that for this scribe at least Jagnā's granth provided a similar degree of textual authority as the volume written by Bhāī Gurdās for Guru Arjan; it may well be that other early scribes also acknowledged multiple sources of textual authority. Two decades after this manuscript was written, Sevāpanthīs ${ }^{67}$ in western Punjab were 'correcting' Adi Granth manuscripts (see below). Despite this increasing concern for textual accuracy, though, there does not seem to have been an immediate effect on the legitimacy accorded to the various recensions of the Granth. Although it is not clear whether certain recensions were popular only among particular groups or in specific geographic

${ }^{65}$ G. B. Singh, Prāchin bīr $\tilde{a}, 167-73$, in which he claims that the date of the manuscript is written on a separate blank folio at the beginning of the volume. A report on the manuscript written by Giānī Garjā Singh in 1966 notes four instances of marginal notations to the text that refer to its having been compared with 'the fifth Guru's Granth' but does not mention a folio bearing the manuscript's date of completion (Giānī Garjā Singh, 'Bhaț̣ vahīã vichõ liā rikārḍ', Punjab Historical Research Department, Punjabi University, Patiala file no 125, 31-2).

${ }^{66}$ F.27b of the manuscript, now bound at the end of the text. The manuscript is in three main hands, the first of which completed the first index, the main index up to Mārū răga, the main text up to Mārū $r \bar{a} g a$ and the passage quoted above. The first index and the completion of the text by the second scribe indicate that the text is of the Lahore recension. It is worth noting that the manuscript bears relatively few actual corrections. Fos 27b-28a would originally have been at the end of the first scribe's index of Mārū rāga, indicating that he did in fact stop writing the text at that point. The above passage was first cited in Piara Singh 'Padam', Srī Guru Granth prakāsh, 89; for a published description of the text, see Piar Singh, Gāthā, 339-42. I have not been able to locate either the Pushkar or Jagnā Brahman granths: I was told in Pushkar in February 1999 that an Adi Granth manuscript formerly owned by a Brahman family in the town had been ceremonially cremated in the early $1990 \mathrm{~s}$.

${ }^{67}$ The Sevāpanth traces its roots back to Bhāī Kanhaiyā, a Khatrī Sikh who joined the community during the lifetime of Guru Tegh Bahadur. Kanhaiyā was well known for carrying out acts of service and is particularly remembered for rendering assistance to wounded soldiers from both sides in the battles of Anandpur during the lifetime of Guru Gobind Singh. The most famous of his successors as mahants were Sevārām and Aḍ̣anshāh, from whom the group takes its alternate names of Sevāpanthīs and Aḍ̣anshāhīs. Before 1947 the group had a large following in western Punjab. The group is well known for its traditions of social service and was formerly renowned for its scribal traditions. A type of ink produced by the group was known as 'Adḍanshāhī ink' 
regions, a chronological examination of the Adi Granth manuscripts at Takht Srī Harimandir Sāhib, Patna is instructive in this regard:

TABle 1. Adi Granth manuscripts at Takht Srī Harimandir Sāhib, Patna

\begin{tabular}{lcccc}
\hline & Lahore & Banno & Damdami & Total \\
\hline 17th century & 6 & 2 & - & 8 \\
18th century & 4 & 23 & - & 27 \\
19th century & - & 10 & 3 & $14^{68}$ \\
20th century & - & - & 1 & 1 \\
\hline
\end{tabular}

Of the Lahore texts, five of the eight seventeenth-century examples and three of the four eighteenth-century volumes subsequently had the compositions characteristic of the Banno recension added to them. The broad conclusions of this survey appear to hold broadly for the surviving corpus of manuscripts as a whole. The earliest manuscripts appear to be independent compilations, including of course the Kartārpur text. In the next stage of development, Lahore recension manuscripts appear to have been predominant until about 1700 , with a number of Banno manuscripts also in existence. After this point, the Banno recension seems to have become at least numerically predominant, and during the eighteenth century a number of earlier Lahore texts were converted into Banno volumes by the addition of the extra Banno compositions. The Damdamī recension appears in an increasing number of copies around the turn of the nineteenth century, although its textual supremacy seems not to have been completely established: the Gurabilāsa Pātashāhī Chheṽ̃ advises readers to correct their manuscripts of the Granth against both the Bhāī Gurdās and the Banno manuscripts. ${ }^{69}$ After the introduction of the printing press to Punjab, the Damdamī text finally dislodged the Banno recension and became the sole source of textual authority. ${ }^{70}$

It would seem that at least part of the impetus towards creating standarized texts of the Adi Granth came from the activities of professional scribes. The testimony of a nineteenth-century scribe and poet from Amritsar district that he had copied five Adi Granths for his livelihood hints at the likely importance of such professional writers in producing and standardizing manuscripts. ${ }^{71}$ It is likely that the role such scribes played was two-fold: on the one hand they would have reified the text of individual recensions; on the other, they would have become part of a 'textual economy' in which they not only responded to but also created demand for specific recensions of the Granth. As we have noted earlier, this may have been the case with the scribes of Damdamā. The

${ }^{68}$ The remaining manuscript is of a rare recension that records the bañ $\bar{l}$ of each of the contributors to the Granth separately rather than in the usual rag $a$-wise arrangement. Its contents are identical to those of the Banno recension.

${ }^{69}$ Bhagat Singh, Gurabilāsa, 151 (adhyāya 4: 409-10). The presence of the injunction in the text is somewhat ironic, since the Gurabilassa is one of the main sources of the modern narrative of the compilation of the Granth and is the text most often used by supporters of the traditional narrative of the Adi Granth's textual history to counter alternate narratives.

${ }^{70}$ At least one printed edition of a Banno text is extant, lithographed at the Giān Press, Gujranwala in 1938 VS/1882 (India Office, London Panj. H21). The text contains the Kabīr pada in Sorathi, the Mīrābā̄i composition in Mārū, the full text of the Sūrdās pada in Sāranga and the apocryphal compositions at the end of the volume, but it has only the first couplet of the M5 chhanta in Rāmakalī rāga.

${ }^{71}$ The scribe, Saundhā, makes the observation in Sikh Reference Library Ms 5435, f. 168, cited in Devindar Singh 'Vidiārthī' (ed.), Srī Gurū Nānak abhinandan (Amritsar: GNDU, 1978), 87, $\mathrm{n} 1$. We are beginning to uncover evidence of other pre-modern scribes who were also fairly active: for non-Adi Granth manuscripts copied by the early eighteenth-century Brahman scribe Sambhū Nāth, see, for example, Panjab University, Lahore Ms 4141; Panjab University, Chandigarh Ms 1132; Punjabi University, Patiala Ms 115154 and Guru Nanak Dev University, Amritsar Ms 52. 
increasing prevalence of illumination and illustration through the eighteenth and nineteenth centuries also argues for the increasing professionalization of the copying of Adi Granth manuscripts. At the same time, it was not just paid scribes whose activities affected the popularity of certain of the recensions of the Adi Granth: Sevāpanthī documents indicate that from at least the early eighteenth century onward members of the group in the Shahpur area were actively engaged in copying out Adi Granth manuscripts and 'correcting' earlier texts in the possession of others. ${ }^{72}$ Such endeavours to correct preexisting Adi Granth manuscripts may have contributed to the cross-fertilization of various recensions and perhaps to the eighteenth-century trend of converting texts of Lahore manuscripts to Banno texts. It would seem, then, that professional and sectarian scribes played a substantial part in both the standardization of manuscripts of the Adi Granth and the popularization of certain recensions.

If the role of professional scribes in the reification of Adi Granth manuscript traditions has hitherto been ignored, so too have those texts that could show the ways the $b \bar{a} n \bar{l}$ was read in pre-modern Punjab. The first group of these are early gutk $\bar{a} \mathrm{~s}^{73}$ and other selective compilations of the Gurus' works. Other than their innate textual interest, the value of early gutkeas lies in what they might be able to tell us about the preferences and choices of those who made selections from the Adi Granth for regular personal reading. Since almost no work has been done on early gutkass, it is extremely difficult even to estimate how many there may be. Important early gutk $\bar{a}$ s include one in the possession of the Soḍ̂̄is of Kartārpur said to be in the hand of Bhā̄i Gurdās; one supposed to have belonged to Guru Hargobind at Gurdwārā Cholā Sahib, Ghurạn̄ị Kalã, district Ludhiana; a volume connected with one of the tenth Guru's wives at Gurdwārā Nānak Jhīrā, Bidar, Karnataka; a volume each said to have belonged to Guru Arjan and Guru Gobind Singh with the Sodhīs of Sangatpurā, district Fatehgarh Sahib; and two volumes bearing scriptural quotations said to be in the hand of Guru Gobind Singh, one with the Bhāi family of Bāgrịã and the other at Srī Gurū Nānak Āshram, Ahraurāa tahsīl Mirzāpur, Uttar Pradesh. Larger collections of selections from the $b \bar{a} n \bar{\imath}$ include a pothī given by the seventh Guru to his daughter Rūp Kaur now at Gurdwārā Mañjī Sāhib, Kīratpur and a similar volume with a quotation from the $b \bar{a} n \bar{l}$ written in the hand of the tenth Guru at Chakk Fateh Singh, zilā Nathānà, district Ferozepur. Such volumes may yield interesting information on changing preferences for specific portions of the bāni and on its transformation from a sung text to one that was read, recited and expounded.

Equally interesting from the point of view of determining the influence and importance of the various recensions of the Adi Granth among literate groups in the eighteenth century are those texts which were composed in deliberate imitation of it. Extant texts include the Pothī Harijasa of the Mīnā Bhāī

\footnotetext{
${ }^{72}$ Nineteenth-century Sevāpanthī texts narrate that when Bhā̄ Sevā Rām went to meet his future teacher Addanshāh in the year $1770 \mathrm{VS} / 1713-14$, Addanshāh was away with his own teacher Gurdās correcting an Adi Granth manuscript belonging to a Mahant Rāmdās of the village Shāh Yūsuf near Shahpur; see Bhāì Sahij Rām, Parachī Bhā̄ Addanashāha kī, ed. Surjit Singh (Patiala: Punjabi University, 1988), 26, 28-9 and Sant Lāl Chand, Srì Santa ratana mālā, ed. Mahant Hīrā Singh. 3rd ed. (Patiala: Hira Singh Mahant, 1955), 63. For the activities of the eighteenth-century scribe Bhāī Rañg in Kartārpur and those of Bhāī Dukhbhañjan in Sahiwal, Shāh Jivvanā and Bherā in the nineteenth century, see Lāl Chand, Srī Santa ratana mālā, 217-18, 417, 509. A manuscript with corrections in another hand dated $1710 \mathrm{VS} / 1653$ and written by a Jat scribe named Gurditt Sekhõ is preserved at the Sevāpanthī Derā Bhā̄ Rāmkishan in Patiala. When I saw the manuscript in December 1993, I was told by the present mahant of the Derā that it was brought from Shahpur district in 1947.

${ }^{73}$ Small prayer books consisting of selections from the Granth.
} 
Darbārī at Vairoke, tahs̄̄l Mogā, Faridkot and the Saina sāgara grantha composed by the devotees of Sain. Quite obviously, the compilers of each of these texts must have had a fixed notion of the correct form of the Granthone that they could reasonably expect their audience to share-in order to know how to structure their own texts. The study of such imitative texts and of early gutkās and pothis would constitute the first tentative steps towards an understanding of the reception of the Adi Granth in seventeenth- and eighteenth-century Punjab. At the same time, there is some scope to investigate the ways in which other texts influenced the way the Granth itself was read. Some Adi Granth manuscripts contain an added marginal notation to the first saloka of the 25 th paurī of Māru ki vāra, claiming that the saloka in question has been 'uttered by Nānū Brahman'. The notation derives from a story in the eighteenth-century Giāna ratanāvalī janamasākhī of Guru Nanak's life in which a Brahman named Nānū recites the verse in the context of a discourse on eating meat. ${ }^{74}$ It would seem that the janams $\bar{a} k h \bar{\imath}$ anecdote has inspired at least some readers of the Granth to attribute the saloka to Nānū, indicating the hold the genre had on the premodern Sikh imagination.

Another important aspect of the ways in which the Adi Granth was read and understood are early commentaries on the text or parts of it. The earliest commentaries on the $b \bar{a} n \bar{\imath}$ are contained in the janams $\bar{a} k h \bar{\imath} \mathrm{s}$, whose narrative units $(s \bar{a} k h \bar{\imath} \mathrm{s})$ often centre around the explication of the context or meaning of an individual shabad by Guru Nanak. ${ }^{75}$ In these texts, the unit of exegesis is the individual shabad, not the scriptural text as a unitary whole; indeed, the janamsākhis seem to comment on oral repertoires of the $b \bar{a} n \bar{\imath}$ rather than on the written text. The next stage of the early commentarial tradition seems to have been the exegetical treatment of some of the more lengthy compositions in the Adi Granth intended for continuous recitation or singing. The earliest among these would seem to have been the late seventeenth-century Mịnā commentaries on compositions of Guru Nanak such as the Japu, Oanikäru, Siddha gosati and the vāra in Āsā rāga, followed by Sevāpanthī Rāmkishan's commentary on Japu completed in $1853 \mathrm{VS} / 1796-97 .{ }^{76}$ The most renowned commentaries on individual sections of the Adi Granth were the Udāsi Anandghan's exegeses of Japu, Áratī sohilā, Oaìkāru, the vāra in Āsā rāga, Siddha gosati and Anandu, completed during the period 1852-59 VS/1795-1803. ${ }^{77}$ Anandghan's occasionally tendentious commentary on Japu caused the ruler of Kainthal, Udai Singh, to commission a response to it by his court poet Bhāì Santokh Singh, who completed his Garaba gañjanī

\footnotetext{
${ }^{74}$ For manuscripts containing the marginal notation, in both cases in another hand, see, for example, Dr Balbir Singh Sahitya Kendra, Dehra Dun acc. no 4982 dated 1736 VS/1679, f. 572 b and Dr Balbir Singh Sahitya Kendra, Dehra Dun acc. no 4990, f. 614a. The second manuscript is undated but is likely to be a mid-eighteenth to mid-nineteenth century production. The notation appears as an integral part of the text of the vära in the 1882 lithographed Banno text of the Adi Granth published at the Giān Press, Gujranwala, although the text also retains the M1 attribution (India Office Panj H21, 1046). For the story of Guru Nanak and Nānū Brahman, see Jasbīr Singh Sābar (ed.), Giāna ratanāval̄ janamasākhī Srī Gurū Nānaka Deva j̄̄ (Amritsar: Guru Nanak Dev University, 1993), 317-22. The earliest extant manuscript of this janamsākhī, not noted or used in Sabar's edition, is Dr Balbir Singh Sahitya Kendra, Dehra Dun Ms 185, dated 1855 VS/1798.

${ }^{75}$ Different janams $\bar{a} k h \bar{\imath}$ traditions - and indeed $s \bar{a} k h \bar{\imath}$ s within individual janams $\bar{a} k h \bar{\imath} \mathrm{s}$ - display varying degrees of engagement with the shabads contained in them, some being content only to provide a frame-story for the composition of the shabad, others subordinating the narrative to exegesis. The first style later developed into the uthanikā tradition of texts which gave framestories for shabads taken from the entire Adi Granth corpus.

${ }^{76}$ For the Mīnāa texts, see for example Central Public Library, Patiala Ms 693; for Rāmkishan's Japu paramārtha, see the manuscripts referenced in 'Ashok', Hatth-likht $\tilde{\bar{a}} d \bar{\imath} s \bar{u} c h \bar{l}$, vol. II, $200-1$.

${ }^{77}$ For the texts of five of the six commentaries, see Ratan Singh Jaggi (ed.), Gurbān̄ tīke: Anandghan (Patiala: Bhasha Vibhag, 1970) and Ratan Singh Jaggi (ed.), 'As $\bar{a}$ dì vār' dā $t \bar{\imath} k \bar{a}$ (țīkākār Suāmī Ānandghan) (Patiala: Punjabi University, 1990).
} 
('Destroyer of pride') in $1886 \mathrm{VS} / 1829{ }^{78}$ Sadānand Udāsī completed a further commentary on the text of Japu in $1890 \mathrm{VS} / 1833 .{ }^{79}$ These explications of individual texts were followed in the nineteenth century by commentaries in the $u$ thānika and paryāi styles that took as their matter the entire text of the Granth: the first style provided narrative settings for shabads, while the second glossed the meanings of individual shabads. ${ }^{80}$ The palpable shift from the individual composition to the continuous text as the unit of commentary that appears to have occurred over the history of the commentarial tradition marks out a concurrent shift in the conception of the $b \bar{a} n \bar{l}$ and the scripture. It also indicates the ascendancy of the written Adi Granth over non-canonical oral

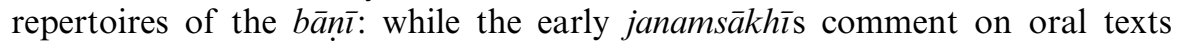
characterized by a number of variant readings and some compositions not contained in the written text, the later commentaries invariably use the written text of the Adi Granth as their basis.

Another aspect of the ways in which the Adi Granth was received and read that will require further study is the development of the practice of its ritual recitation. The most important modern manifestation of the practice is the akhand patth or continuous reading of the text, usually over a period of three days, which comprises the most important ritual use of the text at present. Most Sikh traditions state that the practice was inaugurated in the eighteenth century by itinerant military groups. ${ }^{81}$ The ultimate origins of the practice would seem to lie in the well-attested Indic practice of the ritual recitation of entire sacred texts such as the Vedas and Purānas. In this sense, the practice would seem to derive from Indic conceptions of the sacred word as potent and efficacious in itself and as capable of producing merit through its correct recitation. The Purānas themselves emphasize the importance of their recitation, and many of the vulgate Purānas contain sections expounding the vidhi or procedure to be followed when reciting them, often within fixed periods of seven or nine days. ${ }^{82}$ The public ritual recitation of sacred texts has become a part of modern sectarian Hinduism as well, most famously in the case of the seven- or nine-day pārāyan pāth (complete recitation) or 24-hour akhand pāth of Tulsīdās's Hindi Rāmacharitamānasa. ${ }^{83}$ It is unclear when the Purānic practice was adapted to vernacular texts such as the Rammacharitamānasa or the Adi Granth. In the case of the Adi Granth, there is nothing in the manuscripts themselves to indicate either the manner in which they were to be recited or how frequently. ${ }^{84}$ The question is worth pursuing, though, since any answer will begin to elucidate the problem of when and how the Adi Granth

${ }^{78}$ For manuscripts of Santokh Singh's commentary, see, for example, Central Public Library, Patiala MSs 2293 and 2891.

${ }_{79}$ The text, Japuji satīka, was preserved in a single manuscript available at the Sikh Reference

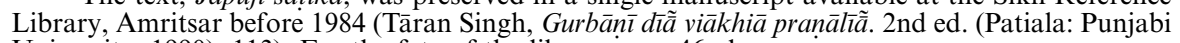
University, 1990), 113). For the fate of the library see n46 above.

${ }^{80}$ For an example of a nineteenth-century uthānike , see Panjab University, Chandigarh Ms 758; for an example of a paryāi, see Chandā Singh, Priyāi A Ai Srī Gurū Granth Sāhib (Amritsar: Harī Singh Gurditt Singh, 1907).

${ }^{81}$ For brief notices of this tradition, see Kāhn Singh Nābhā, Mahān kosh, 40 and Harbans Singh (ed.), Encyclopedia of Sikhism. Vol. I (Patiala: Punjabi University, 1992), 63.

82 Giorgio Bonazzoli, 'Composition, transmission and recitation of the Purāna-s', Purāna 25/2 (July 1983), 258-60, 269-73.

${ }_{83}$ Philip Lutgendorf, The life of a text: performing the Rāmcharitmānas of Tulsidas (Berkeley: University of California Press, 1991), 54-5, 59. As in the Sikh case, these public recitations are usually associated with 'some specific material or spiritual end' (Lutgendorf, The life of a text, 60).

${ }^{84}$ Some extant manuscripts of the Granth contain 'bhog marks' on empty folios at the beginning or end of the text, svastikas in sandalwood paste that were traditionally put on texts to mark the completion (bhog) of a complete reading. Not all texts contain the marks, and those that do often contain a very small number of such marks. The bhog marks cannot, however, be used on their own to assess the frequency of the practice in the pre-modern Panth since it is unclear under what circumstances or how regularly the practice was followed. 
came to be seen not as a compilation of shabads to be sung or recited on their own ${ }^{85}$ but primarily as a continuous text intended for recitation.

In addition to the multiple issues raised by the ways in which the Adi Granth was received as a text, textual study of the Sikh scripture must also come to terms with a number of alternate textual traditions of the works of the Gurus. Within the wider Sikh tradition, the most notable such corpus is the selection of Guru Nanak's compositions recorded in the various janamsākh $\bar{\imath}$ accounts of his life. The earliest known janamsākhi manuscript is a text of the Purātan tradition dated $1697 \mathrm{VS} / 1640$, while the earliest known text of the popular Bālā tradition is dated 1715 VS/1658 and the Miharbān tradition claims to have its roots in the same period. ${ }^{86}$ These janamsākhis are thus comparable in age to the early Adi Granth manuscripts that have been used in previous textual studies on the Granth. Like the independent compilations of the $b \bar{a} n \bar{\imath}$ discussed earlier, the janams $\bar{a} k h \bar{\imath}$ versions of the works of Guru Nanak display the types of variant readings characteristic of distinct oral repertoires of the $b \bar{a} n \bar{\imath}$ and also attribute to Guru Nanak compositions not present in the Adi Granth. As such, these early janamsākhīs are an as yet untapped set of sources for an understanding of the transmission of the works of Guru Nanak, particularly the growth and development of a corpus of works independent of the Adi Granth. Unfortunately, most editors of early janam$s \bar{a} k h \bar{\imath}$ texts have corrected the compositions of Guru Nanak as they appear in the texts against their Adi Granth cognates, making any understanding of their seventeenth-century form impossible. In addition, very few editors have included more than a few eighteenth- or nineteenth-century manuscripts in their editions, thereby making it difficult to see whether later scribes feel compelled to correct their own texts against the Adi Granth. It is also unclear at this stage whether the janamsākhi readings of the works of Guru Nanak cross-fertilize each other in the way that the narrative traditions come to do so in the later compilations. As a result, we have until now been deprived of an understanding of the ways in which non-canonical versions of Guru Nanak's compositions fared in competition with the scriptural text. A similar neglect has plagued early texts on Guru Amardas, Farīd and Kabīr, all of which contain variant versions of the compositions of their subjects. ${ }^{87}$ Outside the Sikh tradition, the major independent corpora of the works of Guru Nanak are from Rajasthan. These are represented by the Sarvāngīs of the Dādūpanthīs Gopāldās and Rajjab, which have between them 105 of the first Guru's compositions. Although the two Sarvāingīs claim to descend from seventeenthcentury originals, they too are only available in eighteenth-century copies. Nonetheless, both texts throw light on the ways in which the words of Guru

\footnotetext{
${ }^{85}$ We have seen above that Guru Nanak Dev University Ms 1245 indexes each rāga separately; the same is true of a number of other seventeenth-century manuscripts, including two seventeenthcentury Lahore recension manuscripts at Takht Srī Harimandir Sāhib, Patna, the second of which was subsequently converted into a Banno text.

${ }^{86}$ For the Purātan text, see Ratan Singh Jaggī and Gursharan Kaur Jaggī (ed.), Purātan janamasākh̄̄ (Patiala: Pavittar Pramānik Prakāshan, 1984); for Bālā, see Gurbachan Kaur (ed.), Janama-sākhì Bhā̄ Bālā dā pāth-pramänīkaran te ālochanātmak sampādan (Patiala: Bhasha Vibhag, 1987); and for Miharbān, see Kirpal Singh and Shamsher Singh 'Ashok' (ed.), Janama sākhī Srī Gurū Nānaka Deva jī. 2 vols. (Amritsar: Khalsa College, 1962-69). For an account of the various traditions, see W. H. McLeod, Early Sikh tradition: a study of the Janam-sākhīs (Oxford: Clarendon Press, 1980), 15-48.

${ }^{87}$ For an early text on Guru Amardas, see Gosati Gurū Amaradāsa kī in Rāe Jasbīr Singh (ed.), Gurū Amardās: Srot pustak (Amritsar: Guru Nanak Dev University, 1986), 43-207; for Kabīr, see Narindar Kaur Bhātīā (ed.), Janamasākh̄̄ Bhagata Kabīra j̄̄ kī (mūlpāth te vivechan) (Amritsar: Guru Nanak Dev University, 1995); for Farīd, see Sant Indar Singh 'Chakravartī' (ed.), Masale Shekha Pharīda ke (Patiala: Bhasha Vibhag, 1962).
} 
Nanak were transmitted outside Punjab in non-canonical circumstances. ${ }^{88}$ Taken together or separately, then, the janamsākh $\bar{l}$ and Rajasthani traditions can tell us a great deal about how Guru Nanak's compositions were received and transmitted in contexts in which the Adi Granth may not have been available.

\section{III}

Without a more solid understanding of the diffusion of early Sikh scriptural manuscripts than we now possess, it is impossible to suggest very much about the connections between allegiance to the early Panth and the possession of volumes of the Granth. Such an understanding would seem to hold out the very real possibility of tracing patterns of allegiance and patronage of shrines through the eighteenth and nineteenth centuries. Unfortunately, the concentrated textual work necessary to provide the background for this type of investigation has yet to be done. Nevertheless, at this stage we can begin to examine both the ways in which the possession of early manuscripts reflects merchant literacy and wealth among groups such as Khatrīs and Arorās and the manner in which the known diffusion of manuscripts highlights the fundamental importance of family lineages in the history of the early Panth.

Any mention of the role of lineage in the context of the pre-modern Panth is bound to bring to mind the descendants of the Gurus: the Sodhi descendants of the Gurus from Ramdas onward, the Bedī descendants of Guru Nanak, the Bhallā descendants of Guru Amardas and the Trehan descendants of Guru Angad. The first two groups in particular were able to perpetuate guru-lineages of their own that in some cases retained their influence until well into the twentieth century, in part due to the generous patronage of Sikh misaldarrs in the eighteenth century and of Mahārājā Ranjīt Singh and his successors in the nineteenth century. ${ }^{89}$ Any history of early Sikh scripture must pay due attention to certain of these lineages, which lay claim to an unusually high number of early texts: the descendants of Guru Hargobind at Kartārpur to the original Adi Granth, the descendants of Guru Ramdas in the village of Gurū Harsahā $\overline{1}$ (district Ferozepur) to a volume that had belonged to Guru Nanak, the descendants of Guru Amardas at Jalandhar and Pinjore to the Goindvāl pothīs, the descendants of Guru Hargobind at Anandpur to a number of old texts, and the shrine established at Dehra Dun in memory of the seventh Guru's eldest son Rāmrāi to an early manuscript said to have been given to him by Guru Har Rai. Early textual scholars took note of many of these texts, and further discoveries may well be made.

It is worth noting at this point the importance of both the $b \bar{a} n \bar{l}$ and the scripture as physical object to the most prominent of the heterodox lines of succession in the early Panth, the Mīnā followers of Guru Arjan's elder brother Prithī Chand. ${ }^{90}$ The Mīnās composed a largely exegetical janamsākhī of Guru Nanak's life in an attempt to situate their own legitimacy in the $b \bar{a} n \bar{l}$ and persona of the first Guru, and extant Mīnā documents indicate a deep reverence for the $b \bar{a} n \bar{l}$ as a whole. A Mīnā account of the life of Prithī Chand's successor Miharbān indicates that he prepared a pothī of $b \bar{a} n \bar{\imath} \bar{\imath}$ ' of all the Gurus' for his

${ }^{88}$ For editions of the Sarvāingīs, see Shahabuddin Iraqi (ed.), Rajjabdās kī Sarbāingī/The Sarbangi of Rajjabdas (A Dadupanthi source of the 17th century). (Aligarh: Granthayan, 1985) and Winand M. Callewaert (ed.), The Sarvāinḡ of Gopāldās: a 17th century anthology of bhakti literature (Delhi: Manohar, 1993).

${ }^{89}$ For remarks on such lineages and their roots in the early Panth, see Harjot Oberoi, The construction of religious boundaries: culture, identity and diversity in the Sikh tradition (Delhi: Oxford University Press, 1994), 108-17.

${ }^{90}$ For an account of the group, see Deol, 'The Mīnās'. 
own regular daily recitation as well as sponsoring the copying of texts of portions of the $b \bar{a} n \bar{l}$ that were distributed to the group's centres. The same document claims that at his death Guru Arjan passed on to Prithī Chand a pothi that was subsequently worshipped and bequeathed to successor gurus of the line as a physical relic. ${ }^{91}$ The exegesis of the Gurus' bāni was central to the group's early claims to legitimacy, and early Mīnā texts often contain select compositions of the Sikh Gurus up to and including Guru Arjan. ${ }^{92}$ Indeed, a compilation intended to be read each night by the seventh Minnā guru Harijī includes compositions of Guru Nanak, Guru Angad and Guru Arjan. ${ }^{93}$ The production of compositions in the style of the Gurus seems also to have been important to the group: Prithī Chand began a tradition of composing with the chhäpa (poetic signature) 'Nanak' that lasted well into the eighteenth century, and we have noted above that early traditions of the composition of the Adi Granth ascribe the decision to compile the text at least partially to the hermeneutic threat posed by such Mīnā compositions. It is clear, then, that the bānñ was important to the legitimation strategies of this heterodox lineage.

At the same time as the Minās were attempting to consolidate their following, it is evident that a number of families were continuing traditions of allegiance to the orthodox line of succession. The names of certain places in Punjab such as the villages of Bhā̄i Rūpe ke, Nausherā Pannūã and Rupeānāa occur repeatedly in the collections of hukamnāmās (letters of the Gurus) published by Ganda Singh and Shamsher Singh 'Ashok'. ${ }^{94}$ Other documents make it clear that families such as the Chhibbar Brahmans of the hilly northwest of Punjab and the descendants of Banno in district Gujrat were also the regular recipients of letters from the Gurus. Such family groups seem to have formed part of a 'core' of followers whose primary allegiance was to the Sikh Panth. Some evidence is beginning to emerge from chronicles to support the supposition that many of these families were important not only in their home regions but also at the Gurus' courts.

An instructive case study is the lineage of Bhāī Banno, the scribe who is said to have made the first copy from Guru Arjan's original text of the Adi Granth. Banno was a Bhātịā Sikh from the village of Khārā Māngat near Gujrat. Local tradition portrayed Banno as having been charged by the Guru with the task of spreading allegiance to the Panth in the areas of Gujrat, Shahpur and Peshawar, and he seems to have been remembered in the region as a worker of miracles. The family remained important through the Guru period and possess letters written to their forebears by Guru Tegh Bahadur, Guru Gobind Singh and Guru Gobind Singh's wife Mātā Sundarī. As we have already noted, the Banno manuscript's date of writing has been altered to 1659 VS/1602 in an attempt to shift it to the lifetime of Guru Arjan, probably in order to gain patronage from Mahārājā Ranjīt Singh. The strategy seems to have been successful, since the Lahore ruler sponsored the construction of a

${ }^{91}$ Govindnāth Rājguru (ed.), Harij̄̄ Sodhī krt Gosati Guru Miharivānu (Chandigarh: Panjab University, 1974), 175, 176-7, 178-9, 352. The text notes Miharbān's love for the bān̄ from an early age and claims that he read the Japu 21 times daily (ibid. 179). A manuscript claimed to have belonged to Guru Nanak was in the possession of Prithî̀ Chand's descendants in Gurū Harsahāi until the 1970s.

${ }_{92}$ Gosati Guru Miharivānu, 170-2, 336, where Harijī is compared to Vyāsa and Shukadeva and made the subject of a prophecy by Guru Nanak that he would explain his bāni. A poth containing the compositions of Hariji and his successor Harinarāin copied in 1802 VŚ 1745 also contains compositions of Guru Nanak and Guru Arjan (Punjabi Úniversity, Patiala Ms 115715).

${ }_{93}$ Khanu Gurū Harij̄ kā răti ke parane ka , Punjabi University, Patiala MS 115715, fos. 23a-25b.

${ }^{94}$ Ganda Singh, Hukamnāme (Patiala: Punjabi University, 1967); Shamsher Singh 'Ashok', Gurū Khālse de nūsān te hukamnāme (Amritsar: Shiromani Gurdwara Prabandhak Committee, 1967). 
shrine in memory of Banno in Khārā Māngat that was begun in 1812 and completed 12 years later. During the same period, the Banno legend consolidated its position as a standard part of the traditional story of the compilation of the Adi Granth. ${ }^{95}$ The manuscript itself was taken to Lahore on the Mahārājā's orders as part of his concerted attempt to collect Sikh relics, ensuring for its custodians a level of patronage that assured them key roles at court. ${ }^{96}$

The post-1850 history of the Banno manuscript is revealing for the ways in which it mirrors the wider history of the Panth: in the 1920s and 1930s the Shiromani Gurdwara Prabandhak Committee fought an unsuccessful court case to gain possession of the manuscript, which remained with the descendants of Banno; ${ }^{97}$ the volume was brought out of Pakistan under military escort during the Partition of 1947, from where it went to Baraut and finally to Kanpur; and in November 1984 the manuscript was thrown into the streets by anti-Sikh rioters aided by local police. The slightly damaged text was subsequently recovered and returned to the $g u r d w \bar{a} r \bar{a}$ built to house it. ${ }^{98}$

While the history of the Banno manuscript is not without its own intrinsic interest, it takes on a new importance in light of the locality's early ties with the Sikh Panth. The town of Khārā Māngat is four and a half miles from the tahsīl headquarters of Phālīa in district Gujrat. Within a 20-mile radius of Phālia lies a number of other towns with long-standing associations to the Sikh community: Mong, Rasūl, Qādirābād, Chakk Fateh Shāh, Vāsū, Bohat, Pindīi Lālā, and Bāhovāl. G. B. Singh has described or mentioned old manuscripts in the first seven villages, while Bāhovāl seems to be the village of origin of the Bāhovāl pothī. ${ }^{99}$ It seems clear that allegiance to the Sikh Panth was quite strong among the mercantile Bhâtịās of the area, the group to which

95 The illustrated manuscript completed in 1843-44 for Soḍhī Bhān Singh of Haranpur begins with a picture of Guru Arjan, Bhā̄ Gurdās and Bhā̄ Banno even though the manuscript itself is of the Damdamī recension (National Museum, New Delhi N.M. 61.1006). This may of course be an attempt to testify to the correctness of the text in accordance with the Gurabilāsa Pātashāhi Chhevĩ's injunction to compare manuscripts with the Banno recension. In this case, the artist has attempted to do this by inserting the story of Banno at the beginning of a Damdami manuscript. It is also equally likely that by the 1840s the story of Banno was so essential to the narrative of the compilation of the Adi Granth that it could not be omitted from so lavishly illustrated a manuscript. Three detached painted folios from the manuscript have been published in Susan Stronge (ed.), The arts of the Sikh kingdoms, 12, 172; B. N. Goswamy, Piety and splendour, 50-3; Karuna Goswamy, Kashmiri painting, 99-101, 153-4, 168-9 (illustrations between 158-9, 142-3, 86-7), where the manuscript has not been identified; and P. Banerjee, The life of Krishna in Indian art (New Delhi: National Museum, 1978), 305.

96 The residents of the village are said to have reciprocated the attentions of the Sikh rulers by sending provisions to the Lahore army during their battle with British troops at Chillianwala in 1849 .

${ }_{97}$ The SGPC fought and lost a similar court case to gain possession of the manuscript now at Kartārpur.

${ }_{98}$ For accounts of the history of the Banno manuscript and the family, see Harmandar Singh, 'Bhāì Banno jī dī Khāre vālī bīr bāre aslīat', Gurmati prakāsh 17: 12 (March 1974), 87-96; Pritam Singh, 'Bhāì Banno's Copy'; and Rājindar Singh Ball, Bhā̄ Banno darpan ate Khāre vālı̀ bīr (Jalandhar: the author, 1989). For local compositions in praise of Banno and his miracles, see Gurdās Singh, Vār Bhā̄ Banno (Gujrat: Harnām Singh, n.d.) and Am̄̄r Singh 'Nūr' Kavīshar, Bhā̄ Banno jō praupkārī (Māngat: Gurdwara Committee Srī Darbār Sāhib Māngat Bhāī Banno, 1925). A longer nineteenth-century hagiography of Banno is Bhā̄ Javāhar Singh Giān̄̄, Bhāà Banno prakāsha, ed. Rājindar Singh Ball (Jalandhar: Coronation Publishers, 1993).

${ }_{99}$ G. B. Singh mentions a hukamnāma of Guru Gobind Singh written to the sangat of Dhaul, zilā Gujrat in the possession of a Māì Budhkī of Peshawar (Prāchīn bīrãa, 336-7). It is not clear whether this is the same document as a hukamnāmā of Guru Gobind Singh to the sangat of Dhaul dated 1764 VS/1707 published in Ganda Singh, Hukamnāme, 186-7. Ganda Singh indicates that the hukamnāmā he publishes was found in the village of Nausherā Pannūã in Amritsar district, and Survey of India maps show a village named Dhaul on the outskirts of Amritsar. It is interesting to note that like the Banno manuscript, the volume at Bohat has had its date of writing altered: in this case, the date $1649 \mathrm{VS} / 1592$ was added in another hand, presumably in a similar attempt to gain patronage (Bhāì Jodh Singh, Prāchīn bīrã bāre bhullā dī sodhan (Lahore: Lahore Bookshop, 1947), 112-14). 
Banno and his descendants belonged. Nearly three-quarters of the Bhâtiāas in district Gujrat declared themselves to be Sikhs in the 1901 Census, a far higher percentage than in other parts of Punjab. Despite this strong Bhâtīa presence, though, G. B. Singh indicates that both Bohat and Vāsū were Aroṛā villages and that the sardārs of Pinḍ̂̀ Lālā were Lāmbā Khatris. ${ }^{100}$ It is, therefore, unclear to what extent the presence of so many manuscripts in the area is evidence of early Bhātīà allegiance to the Panth or of that of the Khatrī and Arorā populations of the area. It is equally uncertain what the textual relationships between the manuscripts in the area were: the only three known to have survived Partition were the Banno manuscript, the Bāhovāl poth $\bar{\imath}$ and the Pinḍ̄ Lālā text, the last of which was in the Sikh Reference Library before 1984. ${ }^{1 \dot{1} 1}$ It is tempting to suggest, however, that Bāhovāl influenced or was copied by one or more of the other early manuscripts in the area.

The Khatrī and Arorā connections evinced in the case of the manuscripts in district Gujrat are part of a larger phenomenon that encompasses most of north India and parts of central Asia. In the case of Punjab itself, the Sevāpanthīs who were writing and correcting Adi Granth manuscripts in early eighteenth-century Shahpur were largely Khatrī and Arorāa ${ }^{102}$ In other parts of north India, the importance of saigats in major commercial towns such as Lucknow, Benares, Patna and Dhaka is shown by the large number of hukam$n \bar{a} m \bar{a}$ s addressed to them in the collections published by Ganda Singh and Shamsher Singh 'Ashok'. The evidence of the writings of Bhāī Gurdās supports the notion that a fair number of the members of these congregations and others in Burhanpur and Agra in the early seventeenth century were Khatrīs and Arorās. ${ }^{103}$ It is not mere coincidence that these cities and others scattered across north India are also home to large numbers of early Adi Granth manuscripts: one gurdwāra in Benares alone was said to have 40 such texts and the main gurdwārā in Patna, as we have already noted, possesses 50 . The cases of Burhanpur and Dhaka are particularly interesting, especially since the Sikh sangats of both cities have received so little attention. The main sarigat in Dhaka, Sangat Tolā, was called the 'Hazūr Sangat' since it was in direct communication with the Guru and collected offerings from other sangats in the area for transmission to the Guru's court. Shrines existed in other parts of Dhaka and in places such as Chittagong, Banigrām and Sylhet; most of these were built through the agency of Udāsi $s \bar{a} d \dot{h} \bar{u}$ s under the supervision of the Nānakmatā shrine in present-day Uttar Pradesh or due to the patronage of Mahã Singh, a Khatrī scribe in the service of "Alīvardī Khān. All of these shrines possessed seventeenth- and eighteenth-century manuscripts, including a finely illuminated volume written for Mahã Singh’s brother Lālā Nand Lāl. ${ }^{104}$

${ }^{100}$ Census of India 1901. Imperial Tables ..., xiii-xci; G. B. Singh, Prāchīn bīra ã , 133, 154. The Bhātīā figure applies to district Gujrat as a whole. Like the Khatrīs and Arorāàs, the Bhâtīās were a mobile mercantile group: in their case, many settled in Sindh and the present-day state of Gujrat and were instrumental in Indian trade with Africa and the Middle East. The Bhātiāas of the area covered by the modern state of Gujrat seem to have followed the Bāniās of the region into the Vallabha sampradāya, probably as a mode of social enhancement; see Richard J. Cohen, 'Sectarian Vaishnavism: the Vallabha Sampradāya', in Peter Gaeffke and David A. Urz (ed.), Identity and division in cults and sects in South Asia. Proceedings of the South Asia Seminar I (Philadelphia: Department of South Asia Regional Studies, University of Pennsylvania, 1984), 65-72.

${ }^{101}$ For the fate of the library, see n46 above.

102 J. Wilson, Gazetteer of the Shahpur district (Lahore: 'Civil and Military Gazette' Press, 1897), 80 .

103 Bhāī Gurdās, Vārãa Bhā̄ Gurdās, ed. Gursharan Kaur Jaggi (Patiala: Punjabi University, 1987), 141-2 (vāra 11: 27, 30-1) and the pre-modern commentary Sikhã dī bhagatamālā, published as Tarlochan Singh Bedi (ed.), Sikhã dì bhagatamālā (Patiala: Punjabi University, 1986), 124-5, 136, $138-42$.

${ }^{104}$ For accounts of the shrines and their manuscripts, see G. B. Singh, Prāchīn bīrã , 274-99. The fate of the shrines and their contents after 1947 is unclear for all but the Dhaka sangats, for 
G. B. Singh indicates that many of the manuscripts in the area shared textual features with those at Nānakmatā, particularly those kept in Udāsī establishments. ${ }^{105}$ Equally apposite is the case of Burhanpur, a town which served as a significant regional entrepôt and the headquarters of Mughal operations in the Deccan during the late seventeenth century. The Khatrī Nānakpanthī presence in Burhanpur seems to have been an important one, and it was to Burhanpur that Hathī Singh, the son of Mātā Sundarī's adopted son Ajīt Singh, resorted in search of followers after he claimed to be Guru in the 1730s. As is to be expected, the sangats of Burhanpur possessed a number of old manuscripts, including some that were connected with Ajīt Singh and Hathī Singh. ${ }^{106}$ Another major centre of Nānakpanthī activity and early manuscripts was Afghanistan, particularly the cities of Kandahar, Kabul, Jalalabad and Ghazni. The sangat of Kabul in particular seems to have had particularly close ties with the Sikh Gurus, and shrines and families in the city possessed a fair number of seventeenth-century manuscripts. As in the case of Dhaka, there were also strong and consistent ties with Udāsī groups. ${ }^{107}$

The presence of large numbers of early manuscripts in cities so closely associated with Khatrī migrations in north India and Arorāa and Khatrī migrations into central Asia seems to argue not only for a reconsideration of the importance of these sangats in the history of Guru-period Sikhism but also for a closer examination of the nexus between merchant literacy, wealth and the possession of scriptural texts. At this stage of research it is impossible to say anything about the relationship between the texts now found in a city or region: further study may suggest whether the manuscripts were copied from one another or if they represent successive waves of importations by different sets of migrants from Punjab. ${ }^{108}$ Nor do we know whether the large proportion of Lahore recension manuscripts in Patna represents a general or local seventeenth-century preference for the recension or is simply a function of the survival of a larger number of Lahore recension texts. If it represents an actual seventeenth-century preference, it would be interesting to know whether that preference is a feature of certain sangats, part of a tradition of copying within the Khatri community or the geographical region they hailed from, a feature of mercantile groups in general, or part of a wider trend within the Nānakpanthī community. In any case, further research into groupings of Adi Granth manuscripts in north India, Bangladesh and Afghanistan is a must. As we have already noted, there is a possibility that the manuscripts in such regions may prove to be textual groups or families in themselves; whether they do or not,

which the buildings still survive but the manuscripts appear to have disappeared. The only manuscript still known to be in Bangladesh is a volume dating to the ninth Guru's lifetime at Sangat Tolā: it was damaged in rioting in 1984 but has apparently since been restored.

${ }_{105}$ Prāchīn bīr $\tilde{\bar{a}}, 287$.

${ }^{106}$ For a brief account of the manuscripts and the state of the sangat in the early twentieth

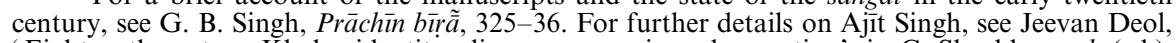
'Eighteenth-century Khalsa identity: discourse, praxis and narrative', in C. Shackle et al. (ed.), Sikh religion, culture and ethnicity (Richmond, Surrey: Curzon, 2000).

${ }^{107}$ For an account of the sangats of Kabul and their manuscripts, see Ganda Singh, Afghänistān $d \bar{a}$ safar. It is not clear what has become of the manuscripts since the beginning of armed conflict in Afghanistan in 1979. Many Afghan Sikhs have migrated to India, and Sikh manuscripts occasionally come on the market at their stopping-off points in Pakistan. An illustrated janamsākhi of Afghan provenance dated $1853 \mathrm{VS} / 1796$ recently appeared on the London art market.

108 A study of variant readings of the Sūrdās pada added to Banno recensions of the Adi Granth indicates that the situation may be a very complex one: most of the texts found in Patna seem to come from a single broad recension, although there are sub-groups within that recension and strong relationships with some texts in Benares and Punjab. One text in Patna seems to come from an independent recension, while manuscripts in Benares seem to come from the Patna recension and two independent textual groups; see Deol, 'Sūrdās', 185-6. It is of course impossible to generalize about the manuscripts as a whole on the basis of the readings of a single pada. 
the correspondences between the manuscripts would indicate not only the relationships between the texts but also ultimately the extent of pre-modern interactions between Nanakpanthī congregations outside Punjab and the extent of their ties with communities in Punjab. Detailed textual study would be useful particularly in demonstrating the extent to which these Khatrī Nānakpanthī textual and religious communities became more or less insular during the course of the eighteenth century and into the period of Ranjit Singh's rule from Lahore.

\section{IV}

As the foregoing pages suggest, the textual study of the Adi Granth is an endeavour that deserves greater attention from scholars of the early Sikh tradition. While research on early scriptural manuscripts in themselves is likely to yield much useful information, there is an urgent need to recontextualize such textual work. Placing the study of scriptural manuscripts within the social contexts of the production and reception of the texts is long overdue. The task is an immense one, likely to require extensive archival research and fieldwork beyond anything thus far carried out in the field of Sikh studies. But the potential gains are almost certainly worth the effort: a renewed, intensive attention to the early history of the Adi Granth is likely to deepen and alter our understanding of the early Sikh Panth. If nothing else, such work will finally shift the discussion of early textual traditions of the Adi Granth away from the limited and damaging context within which previous textual work has been carried out. 